\title{
Listeria survival after isoelectric solubilization and precipitation of fish protein with organic acids
}

Rachel Otto

West Virginia University

Follow this and additional works at: https://researchrepository.wvu.edu/etd

\section{Recommended Citation}

Otto, Rachel, "Listeria survival after isoelectric solubilization and precipitation of fish protein with organic acids" (2010). Graduate Theses, Dissertations, and Problem Reports. 4639.

https://researchrepository.wvu.edu/etd/4639

This Thesis is protected by copyright and/or related rights. It has been brought to you by the The Research Repository @ WVU with permission from the rights-holder(s). You are free to use this Thesis in any way that is permitted by the copyright and related rights legislation that applies to your use. For other uses you must obtain permission from the rights-holder(s) directly, unless additional rights are indicated by a Creative Commons license in the record and/ or on the work itself. This Thesis has been accepted for inclusion in WVU Graduate Theses, Dissertations, and Problem Reports collection by an authorized administrator of The Research Repository @ WVU. For more information, please contact researchrepository@mail.wvu.edu. 


\title{
Listeria Survival After Isoelectric Solubilization and Precipitation of Fish Protein with Organic Acids
}

\author{
Rachel Otto
}

Thesis submitted to the

Davis College of Agriculture, Natural Resources and Design

at West Virginia University

in partial fulfillment of the requirements

for the degree of

\section{Master of Science}

In

Human Nutrition and Foods

\author{
Kristen E. Matak, Ph. D., Chair \\ Jacek Jaczynski, Ph. D. \\ Susan Partington, RD, Ph. D \\ Department of Animal and Nutritional Sciences
}

Morgantown, West Virginia

2010

Keywords: Listeria innocua, Listeria monocytogenes, isoelectric solubilization/precipitation, organic acid, trout 


\section{ABSTRACT \\ Listeria Survival After Isoelectric Solubilization and Precipitation of Fish Protein with Organic Acids}

Rachel Otto

With mechanical fish processing, a substantial amount of protein is discarded as byproducts. Isoelectric solubilization and precipitation (ISP) is a process that recovers previously discarded protein using extreme $\mathrm{pH}$ shifts to solubilize and precipitate protein from byproducts. Typically, strong acids are used for $\mathrm{pH}$ reduction but have limited impact on bacterial load; therefore, organic acids were used during ISP processing to test the impact on Listeria ssp. concentrations. The goals of these studies were to determine the effectiveness of organic acids, specifically acetic and citric acids, to reduce $L$. innocua during the protein recovery process of ISP and to determine if L. innocua is an appropriate surrogate for L. monocytogenes in future ISP processing studies.

Headed, gutted rainbow trout were inoculated with $L$. innocua or $L$.

monocytogenes, homogenized, and brought to the target $\mathrm{pH}$ with granular citric acid $(\mathrm{pH}$ 2.0 and 2.5) or glacial acetic acid ( $\mathrm{pH} 3.0$ and 3.5). Proteins were solubilized for $10 \mathrm{~min}$ at $4{ }^{\circ} \mathrm{C}$ and insoluble components (skin, insoluble protein, etc.) were removed by centrifugation. The remaining solution was $\mathrm{pH}$ shifted to the protein isoelectric point $(\mathrm{pH}$ 5.5) with sodium hydroxide and precipitated protein was separated from the water. Microbial content for each component (proteins, insolubles, and water) was enumerated on both growth and selective media. The sums of the surviving cells from each component were compared to the initial inoculum numbers. No significant differences were observed between the selective and growth media $(P>0.05)$. Significant reductions were detected at all pHs $(P<0.05)$ using $L$. innocua. The greatest reduction in $L$. innocua cells was at $\mathrm{pH} 3.0$ with glacial acetic acid, resulting in a net pasteurization effect (6-log reduction in Listeria populations) with a mean log reduction of 7.64 in the combined components, and a $\log$ reduction of 7.89 in the protein portion. With $L$. monocytogenes, significant reductions were detected at all pHs $(P<0.05)$. However, there were no significant differences in reduction $(P>0.05)$ detected in any of the components between treatments. The greatest reductions were at $\mathrm{pH} 3.0$ with acetic acid, with a mean log reduction of 3.03 in the combined components, and a 3.53 log reduction in the protein portion. Data were compared between the two studies. Significant differences $(P<0.05)$ in recovery were found between the two species at $\mathrm{pH} 2.0$ and 3.0, regardless of processing $\mathrm{pH}$ or acid type, with a greater recovery of L. monocytogenes. These results demonstrate that while organic acids possess anti-microbial potential in ISP processing, the variability in resistance between species indicates that L. innocua is not an appropriate surrogate for L. monocytogenes during ISP processing. 


\section{ACKNOWLEDGEMENTS}

This work was supported by the USDA Hatch program (project nr WVA00429 and WVA00460) and the UDSA Cooperative Research Education and Extension Service (\#2006-34386-17605).

My gratitude is extended to the faculty and staff of the Department of Animal and Nutritional Sciences for their continual help, instruction, and assistance. Special thanks to Sarah Beamer for her assistance and patience with this endeavor. I would like to thank Lancya Lansdowne for her time and guidance during this project.

I would like to extend my sincere appreciation and gratitude to my committee: Dr. Kristen Matak, Dr. Jacek Jaczynski, and Dr. Susan Partington. Thank you all for the great amount of time spent, energy expended, and knowledge shared during this project. Dr. Kristen Matak, thank you for this opportunity, your words of encouragement, and your continued support.

Thank you to my family, friends, and fellow graduate students for your support. 


\section{TABLE OF CONTENTS}

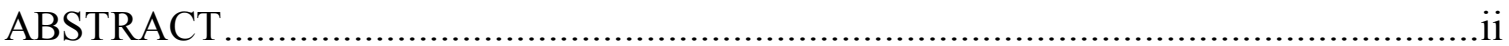

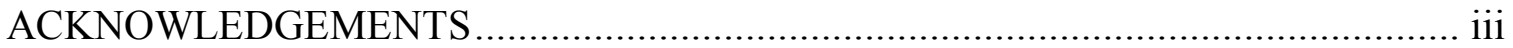

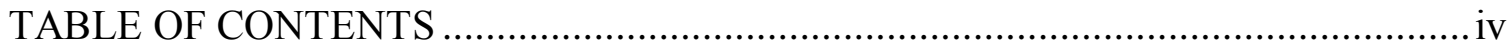

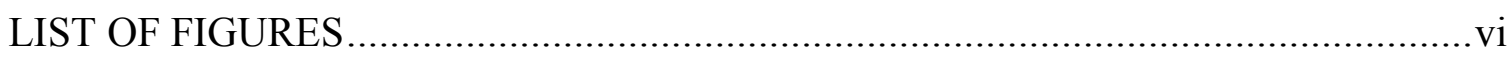

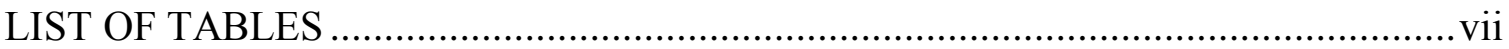

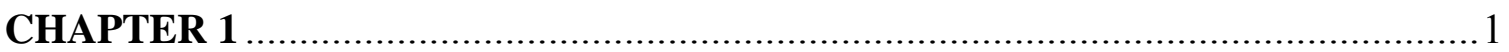

GENERAL INTRODUCTION ........................................................................... 1

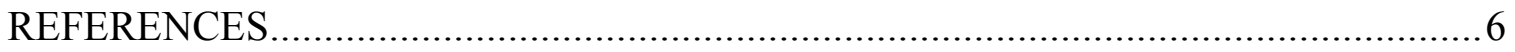

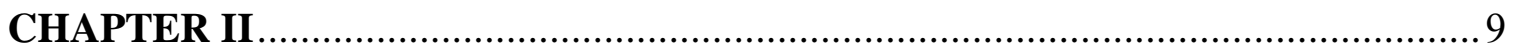

SURVIVAL OF LISTERIA INNOCUA AFTER ISOELECTRIC

SOLUBLIZATION/PRECIPITATION WITH ACETIC ANC CITRIC ACIDS

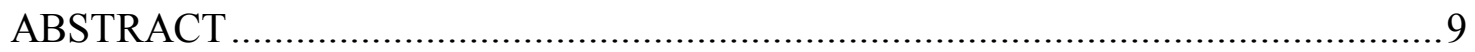

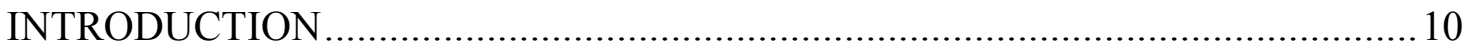

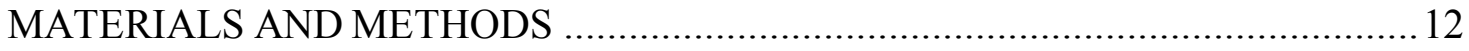

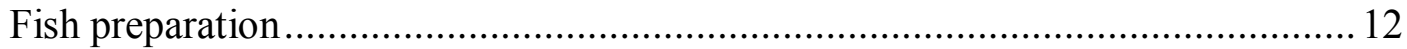

Bacterial strain and inoculum preparation .................................................. 12

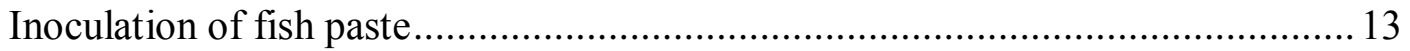

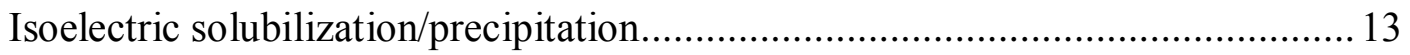

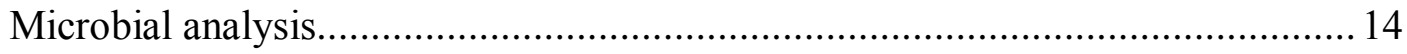

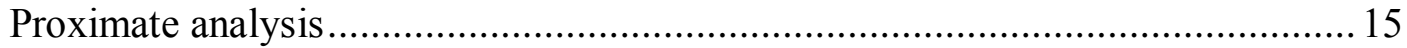




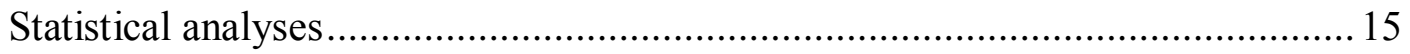

RESULTS AND DISCUSSION ............................................................. 16

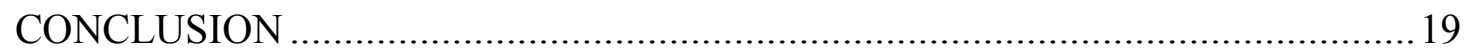

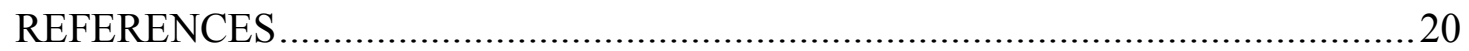

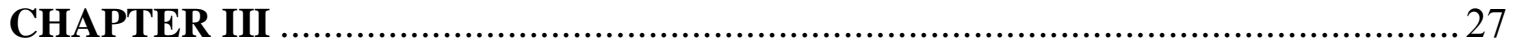

SURVIVAL OF LISTERIA MONOCYTOGENES AFTER ISOELECTRIC SOLUBLIZATION/PRECIPITATION WITH ACETIC ANC CITRIC ACIDS

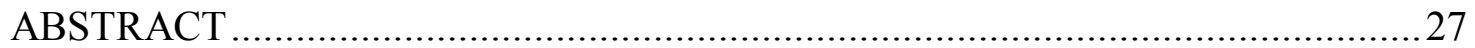

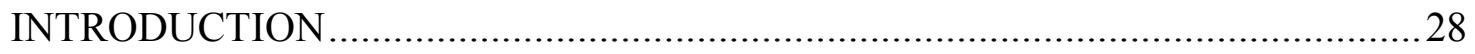

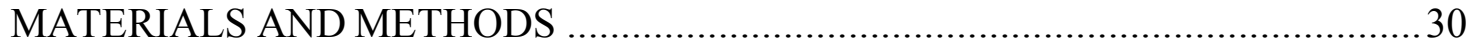

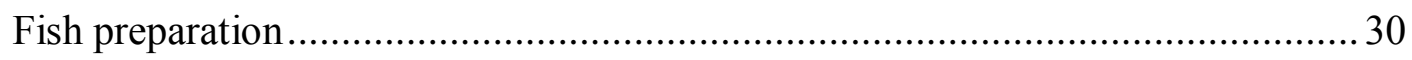

Bacterial strain and inoculum preparation ............................................ 30

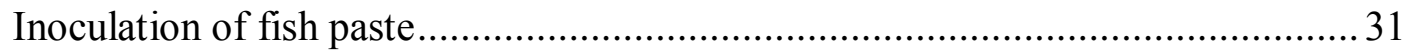

Isoelectric solubilization/precipitation.............................................. 31

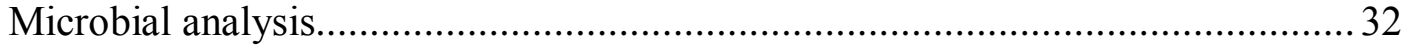

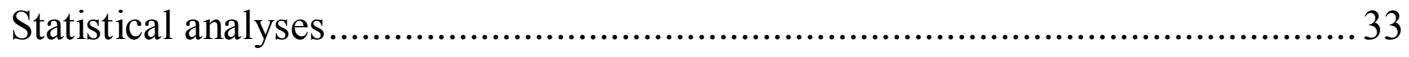

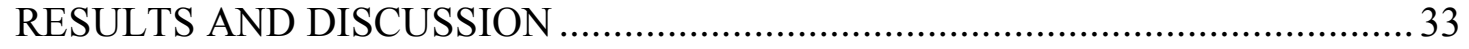

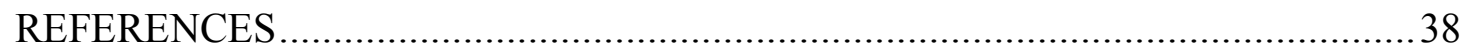




\section{LIST OF FIGURES}

\section{CHAPTER II}

Figure 1. A flowchart for isoelectric solubilization/precipitation for headed and gutted rainbow trout and analyses of recovered components.

Figure 2. Recovered L. innocua after ISP processing with acetic and citric acids at $\mathrm{pH}$ 2.0, 2.5, 3.0, and 3.5. The left pie chart represents the percentage of inactivated and recovered cells from the initial inoculum. The right pie chart represents the component in which the recovered cells were found. Data represents combined recovery on TSAYE and MOX, as there were no significant differences in recovery $(P>0.05)$. Total log reduction was calculated as follows: $\log$ (initial inoculum)- $\log$ (survivors in insoluble fraction + protein fraction + water fraction). Log reduction for each fraction: $\log ($ initial inoculum)- $\log$ (survivors in fractions).

\section{CHAPTER III}

Figure 1. Recovery process of functional proteins with isoelectric solubilization and precipitation.

Figure 2. Recovered L. monocytogenes after ISP processing. The left pie chart indicates the percentage of recovered and inactivated (lost) cells from the initial inoculum. The right chart represents the fraction in which the recovered cells were found. Data represents combined recovery on TSAYE and MOX, as there were no significant differences in recovery $(P>0.05)$. Total log reduction was calculated as follows: $\log$ (initial inoculum)- $\log$ (survivors in insoluble fraction + protein fraction + water fraction). Log reduction for each fraction: $\log$ (initial inoculum)- $\log$ (survivors in fractions). 


\section{LIST OF TABLES}

\section{CHAPTER II}

Table 1. Reduction of L. innocua by ISP processing with citric and acetic acids in rainbow trout. Values were determined by subtraction of the log of recovered cells within a fraction from the log of the total inoculation. There were no significant differences in recovery between TSAYE and MOX $(P>0.05)$. Values designated with the same letter within column and fraction are not significantly different $(P>0.05)$. $\ldots 25$

Table 2. Proximate analysis of recovered trout proteins and insolubles that were solubilized at various $\mathrm{pH}$ values with acetic and citric acids and precipitated at $\mathrm{pH} 5.5$. Values designated with the same letter within a column are not significantly different $(P$ $>0.05)$.

\section{CHAPTER III}

Table 1. Log reduction of L. monocytogenes lab strain FSL X1-003 (L-2289) exposed to acidic $\mathrm{pH}$ shifts with the addition of acetic or citric acids in various fractions of headed and gutted rainbow trout. Values were determined by subtraction of the log of recovered cells within a fraction from the log of the total inoculation. There were no significant differences in recovery between TSAYE and MOX $(P>0.05)$. Values designated with the same letter within column and fraction are not significantly different $(P>0.05) . \ldots 43$

Table 2. Total (protein, insoluble, and water fractions combined) $\log$ reductions of $L$. monocytogenes (LI) and L. innocua (LI) exposed to different $\mathrm{pH}$ shifts using acetic and citric acids in rainbow trout. Values were determined by subtraction of the log of total recovered cells from the log of the total initial inoculation. Combined data from MOX and TSAYE. There were no significant differences in recovery between MOX and TSAYE $(P>0.05)$ 


\section{CHAPTER I}

\section{GENERAL INTRODUCTION}

The sale of rainbow trout (Oncorhynchus mykiss) totaled \$74.9 million in the U.S. in 2007, exceeding 2005 sales by $8 \%$ (USDA 2007). During the commercial processing of rainbow trout, about one-third of the protein is lost because it is difficult to remove from the skeleton, skin, viscera, fins, and head (Lansdowne and others 2009). Approximately $60-70 \%$ of these byproducts are discarded while the rest are used as compost or in animal feed (Chen and Jaczynski 2007). A novel method where fish processing by-products are homogenized into a slurry and the proteins precipitated out using the principle of isoelectric point yields a high quality protein that could be used in value-added products (Chen and Jaczynski 2007). Exposure of fish byproducts in solution to extreme $\mathrm{pH}$ shifts causes separation of insoluble components (bones, scales, skin, etc...) from the protein and water. Protein is recovered by returning the solution to its isoelectric point and subsequent centrifugation. This process is referred to as isoelectric solubilization and precipitation (ISP). Additional processing of the recovered protein may be used in foods intended for human consumption.

Exposure to extreme $\mathrm{pH}$ shifts, such as those required during the ISP process, has had inhibiting effects on the survival and growth of Listeria (Lansdowne and others 2009; Guilbaud and others 2008). It has been shown that only $2.4 \%$ of Listeria would survive exposure to $\mathrm{pH} 3.3$ for $1 \mathrm{hr}$ while exposure to $\mathrm{pH} 3.0$ for $1 \mathrm{hr}$ would leave no survivors (Phan-Thanh and Montagne 1998). Hydrochloric acid (HCl) was utilized in a study that looked at the antimicrobial effect of ISP processing by Lansdowne and others (2009) with the target $\mathrm{pH}$ of 2.0 or 3.0. Results from this study failed to show a net 
pasteurization effect, defined by the USDA (2001) as a 6-log reduction in microbes. It has been demonstrated that weak, organic acids have a more deleterious effect on Gram positive microbes (Vasseur and others 1999; Phan-Thanh and Montagne 1998; Carpenter and Broadbent 2009). Organic acids are commonly used in the food industry to combat growth of Listeria (Carpenter and Broadbent 2009), and may be applied by a wash, spray, dip, or included in product formulations. Inhibitory effects of organic acids can be explained by their ability to passively diffuse through the cell membrane (Vasseur and others 1999). The acid accumulates within the cell cytoplasm where it is then able to dissociate, acidify the cytoplasm, and inhibit substrate transport. Inhibitory effects of acids can be correlated with their dissociation constant ( $\mathrm{pKa}$ value). The larger the $\mathrm{pKa}$, the lesser the extent of dissociation of acid in solution and the greater the dissociation within the cell. In Phan-Thanh and Montagne (1998), results show that when acetic acid is used rather than $\mathrm{HCl}$ to create an extracellular $\mathrm{pH}$ of 3.5 , intracellular $\mathrm{pH}$ is lower with the use of acetic acids (pHs of 3.34 and 4.22, respectively). Additionally, it is hypothesized by Carpenter and Broadbent (2009) that intracellular concentration of anions and release of protons is directly related to the $\mathrm{pH}$ of external solution and external anion concentration.

Listeria monocytogenes is a Gram-positive, food borne pathogen that is responsible for approximately $27 \%$ of deaths related to food-borne illness in the US (Mead and others 1999). L. monocytogenes may be found in a wide range of ready-to-eat cold foods (Van Coillie and others 2004; Shen and others 2006), milk and milk products (Farber and Peterkin 1991; McLauchlin 1996), fresh produce (Beuchat 1996; Thunberg and others 2002), meats (Van Coillie and others 2004), and in raw and cooked seafood 
(Eklund and others 1995; Jorgensen and Huss 1998; Moharem and others 2007). While infection in healthy adults and children is rare, L. monocytogenes may cause septicemia, bacterial meningitis and/or encephalitis with a mortality rate of $20-30 \%$ in an immunocompromised population (Ramaswamy and others 2007). Miscarriage, premature birth, or meningitis in newborns may occur if listeriosis is contracted during pregnancy (Ramaswamy and others 2007).

Listeria has the ability to develop levels of acid resistance or acid tolerance when subjected to sublethal pH levels (Shen and others 2006; Moorman and others 2008; PhanThanh and Montagne 1998; Ferreira and others 2003). L. monocytogenes in slightly acidic food will resist highly acidic treatments by upregulating specific proteins that alter the structure of membranes, increasing the cell's ability to maintain intracellular $\mathrm{pH}$. In addition to acid tolerance, nutrient and protein rich media modifies phospholipids in bacteria, allowing L. monocytogenes to survive otherwise lethal acidic conditions (PhanThanh and Montagne 1998). One mechanism that contributes to bacterial survival under stressors is redirection of transcription through alternative sigma factors. Sigma factors are protein subunits that enable binding of bacterial RNA polymerase to specific gene promoters. $\sigma^{\mathrm{B}}$, a sigma factor seen in Gram positive bacteria, plays a role in the acid tolerance exhibited by Listeria (Raengpradub and others 2008).

Contamination of fish and seafood with Listeria most often occurs within the processing setting. In a study by Wulff and others (2006), no raw fish samples tested positive for Listeria contamination before processing, but $27 \%$ of samples contained Listeria after processing. Additionally, the same authors found moderate to high levels of L. monocytogenes contamination in some of their smokehouses after cleaning and 
disinfection. Initial contamination likely occurs from poor hygiene practices of healthy humans with unknown Listeria infection, which then spreads to other humans, equipment, contact surfaces and the product itself (Swaminathan 2001). Listeria also possesses the ability to form biofilms that readily attach to glass, stainless steel, rubber, and other surfaces (Swaminathan 2001). Some strains of Listeria can persist for months and up to years (Wulff and others 2006). If resistance is related to acid tolerance, Listeria may be more acid resistant than initially believed and have a lesser reaction to $\mathrm{pH}$ shifts used in ISP processing.

L. innocua is the most commonly encountered of the 6 known Listeria species. $L$. innocua is the only species in the same phylogenetic cluster as L. monocytogenes (Chen and others 2009). Recently, L. innocua has been used as a surrogate for $L$. monocytogenes in studies examining different antimicrobial effects of processing treatments. Chill brine and lactic acid bacteria treatments (Boyer and others 2009), temperature treatments (Nufer and others 2007), liquid smoke treatments (Milly and others 2008), high pressure homogenization and nisin treatments (Pathanibul and others 2009), and organic and inorganic acid treatments (Otto and others 2010, Lansdowne and others 2009) have all utilized L. innocua as a surrogate. However, there is no data available comparing $L$. monocytogenes and $L$. innocua survival rates during processing that utilizes extreme $\mathrm{pH}$ shifts.

At the time of publication of this thesis, there were no studies examining the effects of organic acids during ISP on Listeria survival. The goals of these studies were to determine the effectiveness of organic acids, specifically acetic and citric acids, to reduce $L$. innocua during the protein recovery process of ISP and to determine if $L$. 
innocua is an appropriate surrogate for L. monocytogenes in future isoelectric solubilization/precipitation studies. 


\section{REFERENCES}

Beuchat L. 1996. Pathogenic microorganisms associated with fresh produce. J Food Prot 59:204-216.

Boyer RR, Matak K, Meadows B, Williams RC, Eifert JD, and Birbari W. 2009. Survival of Listeria monocytogenes, Listeria innocua, and lactic acid bacteria in chill brines. J Food Sci 74(5): M219-M223.

Carpenter CE and Broadbent JR. 2009. External concentration of organic acid anions and $\mathrm{pH}$ : key independent variables for studying how organic acids inhibit growth of bacteria in mildly acidic foods. J Food Sci 74(1): R12-R15.

Chen J, Jiang L, Chen X, Luo X, Chen Y, Yu Y, Tian G, Liu D and Fang W. 2009. Listeria monocytogenes serovar $4 \mathrm{a}$ is a possible evolutionary intermediate between Listeria monocytogenes serovars $1 / 2 \mathrm{a}$ and $4 \mathrm{~b}$ and L. innocua. J Microbial Biotechnol 19(3):238-249.

Chen Y and Jaczynski J. 2007. Protein recovery from rainbow trout (Oncorhynchus mykiss) processing byproducts via isoelectric solubilization/precipitation and its gelation properties as affected by functional additives. J Agric Food Chem 55:9079-9088.

Eklund M, Poysky F, Paranjpye R, Lashbrook L, Peterson M, and Pelroy G. 1995. Incidence and sources of Listeria monocytogenes in cold-smoked fishery products and processing plants. 58:502-508.

Farber J, and Peterkin P. 1991. Listeria monocytogenes, a food-borne pathogen. Microbiol Rev 55:476-511.

Ferreira A, Sue D, O'Byrne CP, and Boor KJ. 2003. Role of Listeria monocytogenes $\sigma^{\mathrm{B}}$ in survival of lethal acidic conditions and in the acquired acid tolerance response. App Environ Microbiol 69(5):2692-2698.

Guilbaud M, Chafesy I, Pilet M, Leroi F, Prevost H, Heraud M, and Dousset X. 2008. Response of Listeria monocytogenes to liquid smoke. J Appl Microbiol 104:1744-1753.

Jorgensen L, and Huss, H. 1998. Prevalence and growth of Listeria monocytogenes in naturally contaminated seafood. Int J Food Microbiol 42:127-131.

Landsdowne LR, Beamer S, Jaczynski J, and Matak KE. 2009. Survival of Listeria innocua after isoelectric solubilization and precipitation of fish protein. J Food Sci 74(4): M201-205.

McLauchlin, J. 1996. The relationship between Listeria and listeriosis. Food Control. 7:187-193. 
Mead PS, Slutsker L, Dietz V, McCraig F, Bresee S, Shapiro C, Griffin PM, and Tauxe RV. 1999. Food-related illness and death in the United States. Emerg Infect Dis 5:607625.

Milly PJ, Toledo RT, and Chen J. 2008. Evaluation of liquid smoke treated ready-to-eat (RTE) meat products for control of Listeria innocua M1. J Food Sci 73(4):M179-183.

Moharem A, Raj A, and Janardhana G. 2007. Incidence of Listeria species in seafood products of Mysore, India. J Food Safety 27:362-372.

Moorman MA, Thelemann CA, Zhou S, Pestka JJ, Linz JE and Ryser ET. 2008. Altered hydrophobicity and membrane composition in stress-adapted Listeria innocua. J Food Prot 71(1):182-185.

Nufer U, Stephan R, and Tasara T. 2007. Growth characteristics of Listeria monocytogenes, Listeria welshimeri, and Listeria innocua strains in broth cultures and a sliced bologna-type product at 4 and $7^{\circ} \mathrm{C}$. Food Microbiol 24:444-451.

Otto R, Beamer S, Jaczynski J, and Matak K. 2010. Survival of Listeria innocua after Isoelectric Solubilization/Precipitation with Acetic and Citric Acids. Submitted for publication.

Pathanibul P, Taylor TM, Davidson PM, and Harte F. 2009. Inactivation of Escherichia coli and Listeria innocua in apple and carrot juices using high pressure homogenization and nisin. Int J Food Microbiol 129(3): 316-320.

Phan-Thanh L and Montagne A. 1998. Physiological and biochemical aspects of the acid survival of Listeria monocytogenes. J Gen Appl Microbiol 44:183-191.

Raengpradub S, Wiedmann M, and Boor KJ. 2008. Comparative analysis of the $\sigma^{\mathrm{B}}$ dependent stress responses in Listeria monocytogenes and Listeria innocua strains exposed to selected stress conditions. Appl Environ Microbiol 74(1) 158-171.

Ramaswamy V, Cresence VM, Rejitha JA, Lekshmi MU, Dharsana KS, Prasad SP, and Nijila HM. 2007. Listeria - review of epidemiology and pathogenesis. J Microbiol Immunol Infect. 40:4-13.

Shen Y, Liu Y, Zhang Y, Cripe J, Conway W, Meng J, Hall G, and Bhagwat A. 2006. Isolation and characterization of Listeria monocytogenes isolates from ready-to-eat foods in Florida. Appl Environ Microbio. 72(7): 5073-5076.

Swaminathan B. 2001. Listeria monocytogenes. In: Doyle MP, Beuchat LR, Montville TJ, editors. Food microbiology: fundamentals and frontiers. $2^{\text {nd }}$ ed. Washington DC: ASM Press. P 383-409. 
Thunberg R, Tran T, Bennett R, Matthews R, and Negash B. 2002. Microbial evaluation of selected fresh produce obtained at retail markets. J Food Prot 65:677-682

[USDA] United States Food and Drug Administration. 2001. Fish and fisheries products hazards and controls guidance: chapter 17. Available from: http://www.fda.gov/Food/GuidanceComplianceRegulatoryInformation/GuidanceDocume nts/Seafood/FishandFisheriesProductsHazardsandControlsGuide/ucm119783.html. Accessed Jan 23, 2010.

[USDA] United States Food and Drug Administration. 2007. Trout Production. Available from: http://jan.mannlib.cornell.edu/usda/nass/TrouProd//2000s/2007/TrouProd-02-262007.pdf. Accessed May 19, 2009.

Van Coillie E, Werbrouck H, Heyndricks M, Herman L, and Rijpens N. 2004. Prevalence and typing of Listeria monocytogenes in ready-to-eat food products on the Belgian market. J Food Prot 67(11):2480-2487.

Vasseur C, Baverel L, Hebraud M, and Labadie J. 1999. Effect of osmotic, alkaline, acid or thermal stresses on the growth and inhibition of Listeria monocytogenes. J Appl Microbiol 86(3):469-76.

Wulff G, Gram L, Ahrens P, and Vogel BF. 2006. One group of genetically similar Listeria monocytogenes strains frequently dominates and persists in several fish slaughter-and smokehouses. Appl Environ Microbiol 72(6):4313-4322. 


\title{
CHAPTER II
}

\section{SURVIVAL OF LISTERIA INNOCUA AFTER SOLUBILIZATION/PRECIPITATION WITH ACETIC AND CITRIC ACIDS}

\begin{abstract}
.
With mechanical fish processing, a substantial amount of protein is discarded as byproducts. Isoelectric solubilization/precipitation (ISP) is a process that uses extreme $\mathrm{pH}$ shifts to solubilize and precipitate protein from byproducts to recover previously discarded protein. Typically, strong acids are used for $\mathrm{pH}$ reduction but they have limited impact on bacterial load; therefore organic acids were used during ISP processing to test the impact on Listeria innocua concentrations. Headed, gutted, rainbow trout were inoculated with L. innocua, homogenized, and brought to the target $\mathrm{pH}$ with granular citric acid ( $\mathrm{pH} 2.0$ and 2.5) or glacial acetic acid ( $\mathrm{pH} 3.0$ and 3.5). Proteins were solubilized for $10 \mathrm{~min}$ at $4{ }^{\circ} \mathrm{C}$ and insoluble components (skin, insoluble protein, etc.) were removed by centrifugation. The remaining solution was $\mathrm{pH}$ shifted to the protein isoelectric point ( $\mathrm{pH}$ 5.5) with sodium hydroxide and precipitated protein was separated from the water. Microbial content for each component (proteins, insolubles, and water) was enumerated on both growth and selective media. The sums of the surviving cells from each component were compared to the initial inoculum numbers. No significant differences were observed between the selective and growth media $(P>0.05)$. Significant reductions were detected at all pHs $(P<0.05)$. The greatest reduction in cells was at $\mathrm{pH} 3.0$ with glacial acetic acid, resulting in a mean log reduction of 7.42 in the combined components, and a log reduction of 7.89 in the protein portion. These results demonstrate the anti-microbial potential of organic acids in ISP processing.
\end{abstract}


KEY WORDS: Listeria; isoelectric solubilization/precipitation; trout; organic acids

\section{Introduction}

The demand for high quality, safe seafood has increased over the past years in the United States. The sale of rainbow trout (Oncorhynchus mykiss) totaled $\$ 74.9$ million in the U.S. in 2007, exceeding 2005 sales by $8 \%$ (USDA 2007). During the commercial processing of rainbow trout, about one-third of the meat and oil is lost because it is difficult to remove from the skeleton, skin, viscera, fins, and head (Lansdowne and others 2009). It is estimated that $60-70 \%$ of these byproducts are discarded while the rest are used as compost or in animal feed (Chen and Jaczynski 2007). High quality protein that could be used in value-added products for human consumption can be recovered through a novel process where fish processing by-products are homogenized into slurry and the proteins precipitated out using the principles of isoelectric point (Chen and Jaczynski 2007). Exposure of fish byproducts in solution to extreme $\mathrm{pH}$ shifts causes separation of insoluble components (bones, scales, skin, etc...) from the protein and water. Protein is recovered by returning the solution to its isoelectric point and subsequent centrifugation. Additional processing of the recovered protein may be used in foods intended for human consumption.

Listeria species are Gram positive bacteria that are sometimes found in ready-toeat cold foods (Van Coillie and others 2004; Shen and others 2006), meat (Van Coillie and others 2004), dairy products (Farber and Peterkin 1991; McLauchlin 1996), fresh produce (Beuchat 1996; Thunberg and others 2002), and in raw and cooked fish (Eklund and others 1995; Jorgensen and Huss 1998; Moharem and others 2007). Some species are responsible for listeriosis, a condition that can lead to brain infection and even death 
(Ramaswamy and others 2007). While the occurrence of Listeria in raw fish is low, the chance of cross contamination by processing equipment is increased, and some strains of Listeria can persist for months or even years in the processing environment (Wulff and others 2006). Exposure of fish and seafood to $\mathrm{pH}$ shifts as a processing method, in cold smoking, in acid decontamination, and in brining has varying effects on the growth and survival of Listeria (Cortesi and others 2009, Guilbaud and others 2008 ).

Multiple studies have demonstrated that Listeria has low acid tolerance (Boyer and others 2009, Davis and others 1996; Konstantinos and others 2003). However, a recent study by Lansdowne and others (2009) demonstrated the antimicrobial limitations of extreme $\mathrm{pH}$ shifts using hydrochloric acid $(\mathrm{HCl})$ to reduce the $\mathrm{pH}$ during the isoelectric solubilization/precipitation (ISP) process. Although microbial reductions were significant, a net pasteurization effect (greater than 6-log reduction) against L. innocua was not attained (Lansdowne and others 2009). Strong acids, including HCl, dissociate completely in solution, and interact with systems that control proton flow into and out of the cell. It has been shown that organic volatile acids, like acetic acid, apply a more toxic effect on Listeria than inorganic acids because weak acids induce a lower intracytoplasmic $\mathrm{pH}$ (Phan-Thanh and others 2000) by dissociating once inside the cell. In fact, the inhibitory effects of organic acids are attributed to their ability to diffuse through the cell membrane, which is permeable to non-dissociated, non-protonated, and lipophyllic weak acids. As a result, acid builds up within the cell cytoplasm, acidification of the cytoplasm occurs, proton-motive force is interrupted, and substrate transport is inhibited (Vasseur and others 1999). Therefore, the objective of this study was to 
evaluate the effectiveness of organic acid, specifically acetic and citric acids, to reduce Listeria innocua during the ISP protein recovery processing of rainbow trout.

\section{Materials and Methods}

Fish Preparation. Fresh rainbow trout (Oncorhynchus mykiss) were headed and gutted. Fish were submerged for $10 \mathrm{sec}$ into a 50ppm bleach solution and allowed to drain for an additional $10 \mathrm{sec}$ (Clorox Regular Bleach, Clorox, Oakland, CA, USA). The trout were then placed in a sanitized food processor (Cuisinart ProClassic7-Cup Food Processor, Cuisinart Co., East Windsor, NJ, USA) and ground to a thick paste. Sanitation was achieved by misting Cuisinart with $70 \% \mathrm{ETOH}$ and placing under UV light (254 nm) for $15 \mathrm{~min}$. The fish paste (155 g) was portioned into freezer bags (Ziplock Freezer Bags, S.C. Johnson \& Son, Inc., Racine, WI, USA) and stored at $-80^{\circ} \mathrm{C}$.

Listeria Strain and inoculum preparation. Listeria innocua ATCC 33090 was revived in sterile brain heart infusion (BHI; unless otherwise stated, all media were from Difco, Becton Dickinson, Sparks, MD, USA) and incubated $18-24 \mathrm{hrs}$ at $37^{\circ} \mathrm{C}$ and $50 \mathrm{RPM}$ in shaking incubator. This initial culture was spread onto sterile slants of tryptic soy agar with $6 \%$ yeast extract (TSAYE), incubated $18-24 \mathrm{hr}$ at $37^{\circ} \mathrm{C}$ and then stored at $4{ }^{\circ} \mathrm{C}$ to create a working stock.

Listeria innocua from the working stock was transferred into $100 \mathrm{~mL}$ sterile BHI flasks and allowed to incubate at $37^{\circ} \mathrm{C}$ and $50 \mathrm{RPM}$ for $18-24 \mathrm{~h}$ in a rotary incubator (Classic C24, New Brunswick Scientific Co., Edison, NJ, USA). Contents of BHI flasks were centrifuged at $10,000 \times \mathrm{G}$ for $10 \mathrm{~min}$ at $4^{\circ} \mathrm{C}$ (Sorvall RC-SB Refrigerated Superspeed Centrifuge, Du Pont, Wilmington, DE, USA). Supernatant was removed and 
remaining unwashed pellet $(\mathrm{avg}=0.2 \mathrm{~g})$ was used to inoculate $155 \mathrm{~g}$ fish paste. The initial target inoculum level was $10^{9} \mathrm{CFU} / \mathrm{g}$ (Lansdowne and others 2009). Actual initial average inoculum level was $3.49 \times 10^{9} \mathrm{CFU} / \mathrm{g}$.

Inoculation of Fish Paste. One $155 \mathrm{~g}$ bag of fish paste was allowed to thaw $18-24 \mathrm{hrs}$ at $4^{\circ} \mathrm{C}$. The fish paste was emptied into an autoclaved ceramic dish. The Listeria innocua pellet (described above) was mixed into the fish paste by hand using an autoclaved spatula. The inoculated fish paste was immediately used in the isoelectric solubilization and precipitation process.

Isoelectric solubilization/precipitation. A description of the recovery process of functional proteins is shown in Figure 1. One hundred seven grams of the previously mentioned inoculated fish paste was placed in an autoclaved $2000 \mathrm{~mL}$ glass beaker. The fish paste was homogenized with $693 \mathrm{~mL}$ distilled, deionized water. The homogenizer (PowerGen 700, Fisher Scientific, Pittsburgh, PA) was sanitized by wiping with $70 \%$ ETOH and dried under UV light $(254 \mathrm{~nm})$ for $15 \mathrm{~min}$. Granular citric acid (Fischer Scientific, Fairlawn, NJ, USA) or glacial acetic acid (Fischer Scientific, Fairlawn, NJ, USA) was added until the homogenate reached the target $\mathrm{pH}(2.0,2.5$ for citric and 3.0, 3.5 for acetic). Once at the target $\mathrm{pH}$, the solution was homogenized for $5 \mathrm{~min}$, during which $\mathrm{pH}$ changes were maintained by addition of citric or acetic acid or $10 \mathrm{~N} \mathrm{NaOH}$. After the adjustment time, the solution was mixed for an additional 10 min for protein solubilization. To separate the insoluble portions of the solution, the homogenized fish mixture was transferred to autoclaved centrifuge tubes and centrifuged at 10,000 x $G$ for 10 min at $4^{\circ} \mathrm{C}$ (Sorvall RC-SB Refrigerated Superspeed Centrifuge, Du Pont, Wilmington, DE, USA). The supernatant, consisting of water and solubilized protein was 
poured through autoclaved cheesecloth into a $500 \mathrm{~mL}$ sterilized glass beaker. The insoluble component, left at the bottoms of the centrifuge tubes, was spooned into a 250 $\mathrm{mL}$ autoclaved glass beaker using an autoclaved spatula. The supernatant was brought to its isoelectric point ( $\mathrm{pH} 5.5$ ) by the addition of $10 \mathrm{~N} \mathrm{NaOH}$ and was homogenized for 5 min. After adjustment to final $\mathrm{pH}$ (5.5), the solution was mixed for an additional $10 \mathrm{~min}$ to allow for protein precipitation. The protein and water solution was poured into autoclaved centrifuge tubes and centrifuged at $10,000 \times \mathrm{G}$ for $10 \mathrm{~min}$ at $4^{\circ} \mathrm{C}$. Following centrifugation, the resulting supernatant, comprised mostly of water, was poured off through autoclaved cheesecloth into an autoclaved $500 \mathrm{~mL}$ flask. The remaining protein fraction, left at the bottoms of the centrifuged tubes, was spooned out using an autoclaved spatula into an autoclaved $250 \mathrm{~mL}$ beaker. Total processing time was approximately 90 $\min$.

Microbial Analysis. Microbial analysis was performed on fish paste (background), inoculated fish paste (initial), and the recovered components: insolubles, protein, and water. One gram from all components (background, initial, insolubles, protein and water) and $9 \mathrm{~mL}$ sterile peptone buffer was placed and mixed in separate, sterile stomacher bags. Each component was serially diluted (tenfold) with sterile peptone buffer and $0.1 \mathrm{~mL}$ was spread plated on both non-selective media (TSAYE) and selective media (modified oxford agar, MOX) in duplicate. The plates were incubated for $24 \mathrm{hrs}$ at $37^{\circ} \mathrm{C}$ (Classic C24, New Brunswick Scientific Co., Edison, NJ, USA). The detection limit for background flora, from the uninoculated fish paste was $<10^{3} \mathrm{CFU} / \mathrm{g},<10^{1} \mathrm{CFU} / \mathrm{g}$ for insolubles, $<10^{1} \mathrm{CFU} / \mathrm{g}$ for protein, and $<10^{1} \mathrm{CFU} / \mathrm{g}$ for the water portion. 
Proximate Analysis. Total fat, crude protein, moisture, and ash contents were determined for the headed and gutted trout paste, recovered proteins, and recovered insolubles. To determine total fat, Soxhelt extraction method was used on a $1 \mathrm{~g}$ sample. Extraction with petroleum ether was performed for $24 \mathrm{~h}$ at a drip rate of $10 \mathrm{~mL} \mathrm{~min}^{-1}$. Total fat content was determined on a gravimetic basis and expressed as $\mathrm{g}$ fat $\mathrm{kg}^{-1}$ sample. Kjeldahl assay was used to determine crude protein, expressed as g protein $\mathrm{kg}^{-1}$. To establish moisture content, A 2 g sample was spread uniformly on aluminum dishes (Fischer Scientific) and oven-dried at $105^{\circ} \mathrm{C}$ for $24 \mathrm{hr}$. To obtain ash content, $2 \mathrm{~g}$ sample was incinerated in a muffle furnace at $550^{\circ} \mathrm{C}$ for $24 \mathrm{~h}$. Ash is expressed as $\mathrm{g}$ ash $\mathrm{kg}^{-1}$. All analyses were performed in triplicate and reported as the mean value (SD).

Statistical Analysis. The experiments were replicated in triplicate for each $\mathrm{pH}$ value. Recovered cells were expressed as $\log _{10} \mathrm{CFU} / \mathrm{g}$. Microbial counts (CFU/g) were converted into logarithmic units and differences were determined by one-way analysis of variance and Tukey-Kramer's honestly significant differences test $(\mathrm{P}<0.05)$ (JMP 7, SAS Inst., Cary, N.C., USA).

\section{Results and Discussion}

The average background flora recovered on TSAYE was $2.21 \times 10^{2} \mathrm{CFU} / \mathrm{g}$ for all trials. No background Listeria cells were isolated on $\operatorname{MOX}\left(<10^{2} \mathrm{CFU} / \mathrm{g}\right)$. Across all trials, there were no significant differences in the number of recovered cells on TSAYE compared to those recovered on $\operatorname{MOX}(P>0.05)$. A net pasteurization effect, defined by the USDA (2001) as a 6-log reduction in microbes, was achieved in all recovered fractions (protein, water, and insolubles) when using acetic acid during the ISP process 
with a target $\mathrm{pH}$ of $3.0(P<0.05)$ (Table 1). The greatest overall cell reductions in all fractions were also found at $\mathrm{pH} 3.0$ with the use of acetic acid $(P<0.05)$. The use of citric acid ( $\mathrm{pH} 2.0$ and 2.5) and acetic acid at $\mathrm{pH} 3.5$ led to reductions in cell populations, but did not yield a net pasteurization effect. The fewest microbial reductions in all fractions were found when the $\mathrm{pH}$ was adjusted with citric acid to $\mathrm{pH} 2.5$. Of the cells recovered after the ISP process, most were found to be in the insoluble fraction, with the exception of citric acid $\mathrm{pH}$ 2.0, where most cells were recovered within the protein fraction. In all cases, the least recovered cells were found in the water fraction (Figure 2). Centrifugation is likely responsible for the concentration of cells in the insoluble component, thus leaving fewer cells to be collected during the second centrifugation in the protein component (Lansdowne and others 2009).

No lipid was recovered during processing with citric and acetic acids at any $\mathrm{pH}$ level. Headed and gutted trout used in processing contained 5.25\% lipid (dry basis). Proximate analysis (Table 2) reveals that up to $4.26 \%$ lipid was located in the protein fractions. Lipid was not detected in the insoluble fractions processed with citric acid at $\mathrm{pH} 2.0$ and 2.5, and with acetic acid at $\mathrm{pH}$ 3.0. Lipid recovered from trout in an ISP study by Chen and Jaczynski (2007) demonstrated that acidic conditions resulted in higher lipid content within the recovered protein than did processing with alkaline conditions. It has been noted that a high fat content in food can have protective effects on pathogens exposed to acidic conditions, with the hypothesis that pathogenic cells become entrapped in hydrophobic lipid moieties, thus evading acidic killing (Waterman and Small, 1998). While the lipid was distributed among the protein and insoluble portions in this study, it does not appear that the lipid concentration was high enough to provide a 
protective effect for L. innocua. As seen in Tables 1 and 2, the greatest amount of lipid found in the protein portions was in the acetic acid at $\mathrm{pH} 3.0$ treatment ( $4.26 \%$ lipid). Use of acetic acid at $\mathrm{pH} 3.0$ also provided the greatest log reduction in the protein portions ( $7.64 \pm 0.04$ on MOX and $8.14 \pm 0.95$ on TSAYE).

In a similar study conducted by Lansdowne and others (2009), a net pasteurization effect was not seen using $\mathrm{HCl}$ during the ISP process despite the target $\mathrm{pH}$ of 2.0 or 3.0. In Vasseur and others (1999), 5 strains of Listeria grown in media with added $\mathrm{HCl}$ or acetic acid showed that acetic acid had a more inhibitory effect at the same $\mathrm{pH}$ as $\mathrm{HCl}$ on the growth of all 5 strains of Listeria. Acetic acid's inhibitory effect can be explained by its ability to passively diffuse through the cell membrane (Vasseur and others 1999). The acid accumulates within the cell cytoplasm where it is then able to dissociate, acidify the cytoplasm, and inhibit substrate transport. Inhibitory effects of acids can be correlated with their dissociation constant (pKa value). The larger the $\mathrm{pKa}$, the lesser the extent of dissociation of acid in solution and the greater the dissociation within the cell. Due to its higher pKa, acetic acid (pKa 4.76) is thought to be a better antimicrobial agent than citric acid (pKa 3.14). Additionally, it is hypothesized by Carpenter and Broadbent (2009) that intracellular concentration of anions and release of protons is directly related to the $\mathrm{pH}$ of external solution and external anion concentration. Listeria has limited ability to survive in acidic conditions. It has been shown that only $2.4 \%$ of Listeria would survive exposure to $\mathrm{pH} 3.3$ for $1 \mathrm{hr}$ and exposure to $\mathrm{pH} 3.0$ for $1 \mathrm{hr}$ would leave no survivors (Phan-Thanh and Montagne 1998). Depending on the composition of media and its $\mathrm{pH}$, survival times may be longer. Fish byproducts containing proteins may provide a rich, proteinaceous media capable of decreasing the 
antimicrobial effectiveness of acids by reducing influx of protons (Landsdowne and others, 2009). When exposed to sublethal acidic media or conditions, Listeria exhibits the ability to better resist a previous lethal acid $\mathrm{pH}$, and may become highly resistant to extremely acidic conditions (Phan-Thanh and Montagne 1998; Davis and others 1996; Koutsoumanis and others 2003). Listeria found in mildly acidic foods, for example, can resist severe acid treatment by upregulating proteins and altering membranes structures that regulate intracellular $\mathrm{pH}$ (Phan-Thanh and Montagne 1998).

Contamination of fish and seafood with Listeria most often occurs within the processing setting. Initial contamination likely occurs from poor hygiene practices of healthy humans with Listeria infection, which then spreads to other humans, equipment, contact surfaces and the product itself(Swaminathan 2001). Listeria also possesses the ability to form biofilms that readily attach to glass, stainless steel, rubber, and other surfaces (Swaminathan 2001). Some strains of Listeria can persist for months and up to years (Wulff and others 2006). If resistance is related to acid tolerance, Listeria may be more acid resistant than initially believed and have a lesser reaction to $\mathrm{pH}$ shifts used in ISP.

\section{Conclusion}

This study investigated the effectiveness of ISP processing using acetic and citric acids to recover protein while reducing populations of L. innocua in fish. There were no significant differences in cell recovery using selective versus growth media. While citric acid significantly reduced bacterial populations, a net pasteurization effect was not 
attained. ISP processing at $\mathrm{pH} 3.0$ with acetic acid resulted in a net pasteurization effect (6-log reduction in pathogens) for the protein, insoluble and water fractions. 


\section{References}

Beuchat L. 1996. Pathogenic microorganisms associated with fresh produce. J Food Prot 59:204-216.

Boyer RR, Matak K, Meadows B, Williams RC, Eifert JD, and Birbari W. 2009. Survival of Listeria monocytogenes, Listeria innocua, and lactic acid bacteria in chill brines. $\mathrm{J}$ Food Sci 74(5): M219-M223.

Carpenter CE and Broadbent JR. 2009. External concentration of organic acid anions and $\mathrm{pH}$ : key independent variables for studying how organic acids inhibit growth of bacteria in mildly acidic foods. J Food Sci 74(1): R12-R15.

Chen Y and Jaczynski J. 2007. Protein recovery from rainbow trout (Oncorhynchus mykiss) processing byproducts via isoelectric solubilization/precipitation and its gelation properties as affected by functional additives. J Agric Food Chem 55:9079-9088.

Cortesi ML, Panebianco A, Giuffrida A, and Anastastio A. 2009. Innovations in seafood preservation and storage. Vet Res Commun 33(Suppl 1):S15-S23.

Davis M, Coote P, and O'Byrne C. 1996. Acid tolerance in Listeria monocytogenes: the adaptive acid tolerance response (ATR) and growth-phase-dependent acid resistance. Microbiology. 142:2975-2982.

Eklund M, Poysky F, Paranjpye R, Lashbrook L, Peterson M, and Pelroy G. 1995. Incidence and sources of Listeria monocytogenes in cold-smoked fishery products and processing plants. 58:502-508.

Farber J, and Peterkin P. 1991. Listeria monocytogenes, a food-borne pathogen. Microbiol Rev 55:476-511.

Guilbaud M, Chafesy I, Pilet M, Leroi F, Prevost H, Heraud M, and Dousset X. 2008. Response of Listeria monocytogenes to liquid smoke. J Appl Microbiol 104:1744-1753.

Jorgensen L, and Huss, H. 1998. Prevalence and growth of Listeria monocytogenes in naturally contaminated seafood. Int J Food Microbiol 42:127-131.

Konstantinos K, Kendall P, and Sofos J. 2003. Effect of food processing-related stresses on acid tolerance of Listeria monocytogenes. Appl Environ Microbiol 69(12):75147516.

Landsdowne LR, Beamer S, Jaczynski J, and Matak KE. 2009. Survival of Listeria innocua after isoelectric solubilization and precipitation of fish protein. J Food Sci 74(4): M201-205. 
McLauchlin, J. 1996. The relationship between Listeria and listeriosis. Food Control. 7:187-193.

Moharem A, Raj A, and Janardhana G. 2007. Incidence of Listeria species in seafood products of Mysore, India. J Food Safety 27:362-372.

Phan-Thanh L and Montagne A. 1998. Physiological and biochemical aspects of the acid survival of Listeria monocytogenes. J Gen Appl Microbiol 44:183-191.

Phan-Thanh L, Mahouin F, and Aligé S. 2000. Acid responses of Listeria monocytogenes. Int J Food Microbiol 55:121-126.

Ramaswamy V, Cresence VM, Rejitha JA, Lekshmi MU, Dharsana KS, Prasad SP, and Nijila HM. 2007. Listeria-review of epidemiology and pathogenesis. J Microbiol Immunol Infect. 40:4-13.

Shen Y, Liu Y, Zhang Y, Cripe J, Conway W, Meng J, Hall G, and Bhagwat A. 2006. Isolation and characterization of Listeria monocytogenes isolates from ready-to-eat foods in Florida. Appl Environ Microbio. 72(7): 5073-5076.

Swaminathan B. 2001. Listeria monocytogenes. In: Doyle MP, Beuchat LR, Montville TJ, editors. Food microbiology: fundamentals and frontiers. $2^{\text {nd }}$ ed. Washington DC: ASM Press. P 383-409.

Thunberg R, Tran T, Bennett R, Matthews R, and Negash B. 2002. Microbial evaluation of selected fresh produce obtained at retail markets. J Food Prot 65:677-682

[USDA] United States Food and Drug Administration. 2001. Fish and fisheries products hazards and controls guidance: chapter 17. Available from: http://www.fda.gov/Food/GuidanceComplianceRegulatoryInformation/GuidanceDocume nts/Seafood/FishandFisheriesProductsHazardsandControlsGuide/ucm119783.html. Accessed Jan 23, 2010.

[USDA] United States Food and Drug Administration. 2007. Trout Production. Available from: http://jan.mannlib.cornell.edu/usda/nass/TrouProd//2000s/2007/TrouProd-02-262007.pdf. Accessed May 19, 2009.

Van Coillie E, Werbrouck H, Heyndricks M, Herman L, and Rijpens N. 2004. Prevalence and typing of Listeria monocytogenes in ready-to-eat food products on the Belgian market. J Food Prot 67(11):2480-2487.

Vasseur C, Baverel L, Hebraud M, and Labadie J. 1999. Effect of osmotic, alkaline, acid or thermal stresses on the growth and inhibition of Listeria monocytogenes. J Appl Microbiol 86(3):469-76. 
Waterman SR, and Small PLC. 1998. Acid-sensitive enteric pathogens are protected from killing under extremely acidic conditions of $\mathrm{pH} 2.5$ when they are inoculated onto certain solid food surfaces. Appl Environ Microbiol 64(10): 3882-3886.

Wulff G, Gram L, Ahrens P, and Vogel BF. 2006. One group of genetically similar Listeria monocytogenes strains frequently dominates and persists in several fish slaughter-and smokehouses. Appl Environ Microbiol 72(6):4313-4322. 
Figure 1. A flowchart for isoelectric solubilization/precipitation for headed and gutted rainbow trout and analyses of recovered components.

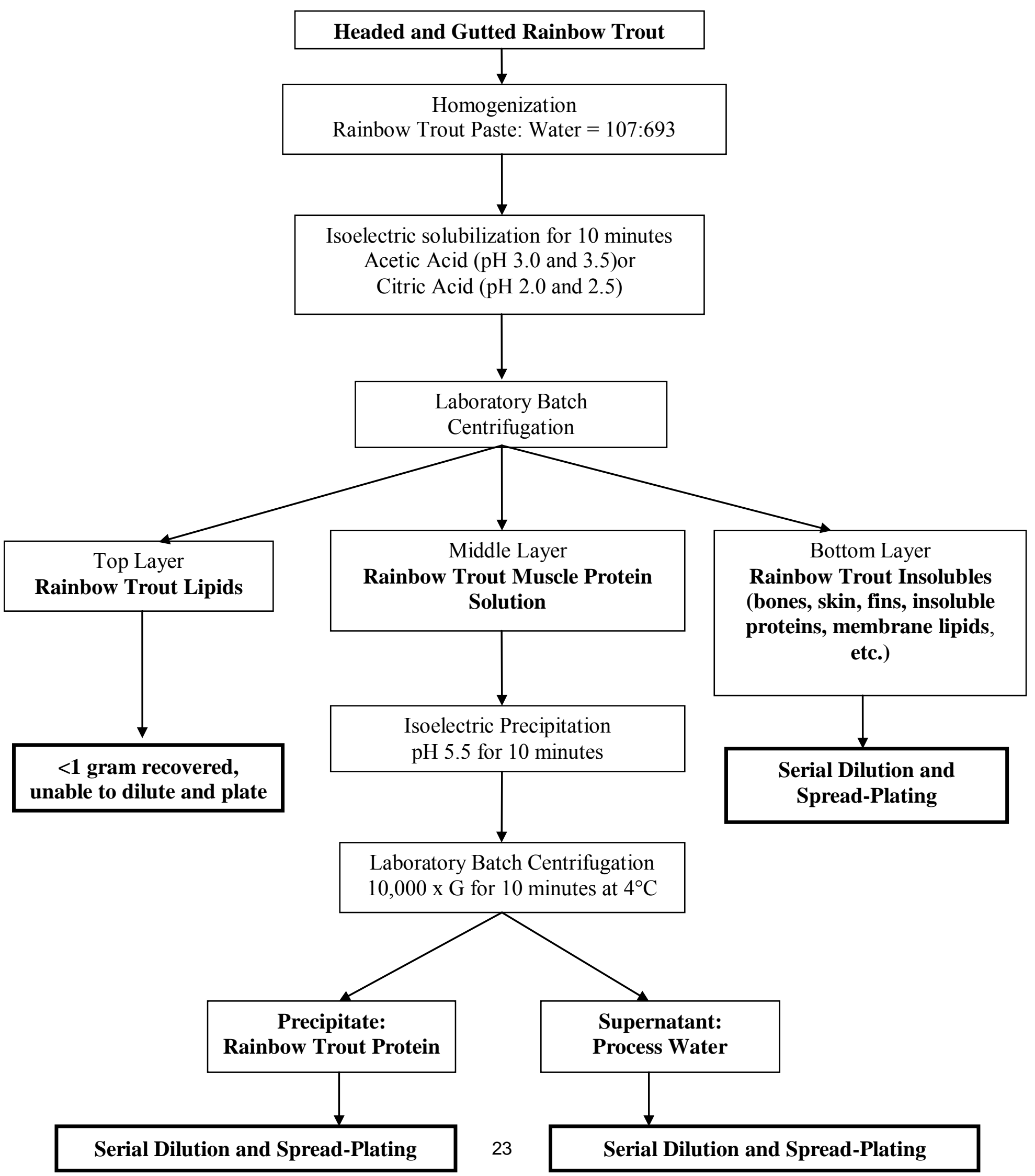



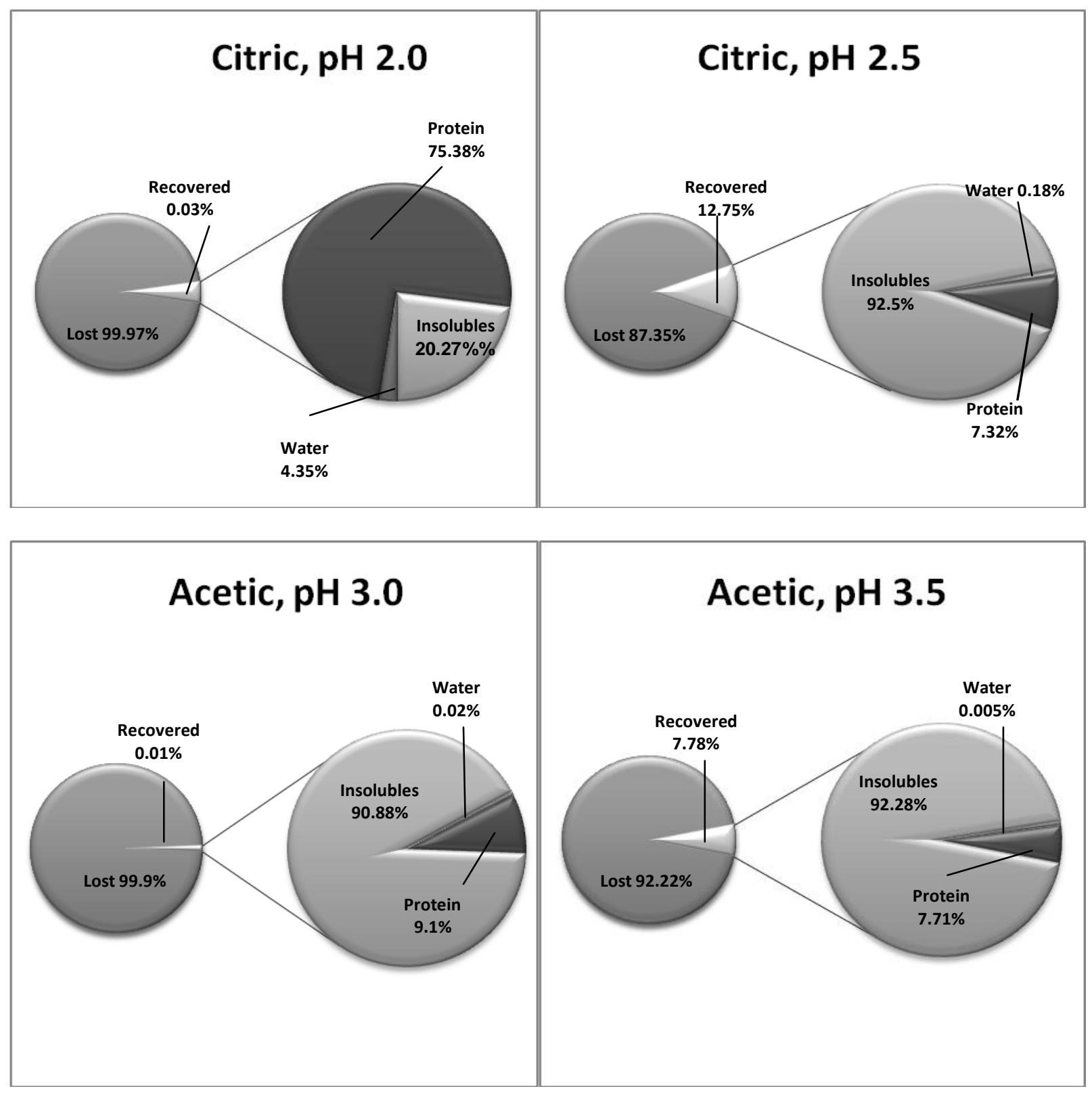

Figure 2. Recovered L. innocua after ISP processing with acetic and citric acids at $\mathrm{pH} 2.0$, 2.5, 3.0, and 3.5. The left pie chart represents the percentage of inactivated and recovered cells from the initial inoculum. The right pie chart represents the component in which the recovered cells were found. Data represents combined recovery on TSAYE and MOX, as there were no significant differences in recovery $(P>0.05)$. Total log reduction was calculated as follows: $\log$ (initial inoculum)- $\log$ (survivors in insoluble fraction + protein fraction + water fraction). Log reduction for each fraction: $\log$ (initial inoculum)$\log$ (survivors in fraction). 
Table 1. Reduction of L. innocua by ISP processing with citric and acetic acids in rainbow trout. Values were determined by subtraction of the log of the recovered cells within a fraction from the log of the total initial inoculation (average: $9.54 \mathrm{CFU} / \mathrm{g}$ ). There were no significant differences in recovery between TSAYE and MOX $(P>0.05)$.

\begin{tabular}{|c|c|c|c|}
\hline \multirow[b]{2}{*}{ Fraction } & \multirow[b]{2}{*}{ Acid/pH } & \multirow[b]{2}{*}{ MOX } & \multirow{2}{*}{$\begin{array}{c}\text { Log Reduction } \\
\text { (mean } \log \mathrm{CFU} / \mathrm{g} \pm \mathrm{SD}, n= \\
\text { TSAYE }\end{array}$} \\
\hline & & & \\
\hline \multirow[t]{4}{*}{ Insoluble } & Citric/2.0 & $4.18 \pm 0.53^{a}$ & $4.58 \pm 0.49^{a}$ \\
\hline & Citric/2.5 & $0.85 \pm 0.33^{b}$ & $1.15 \pm 0.26^{b}$ \\
\hline & Acetic/3.0 & $7.64 \pm 0.04^{c}$ & $8.15 \pm 0.94^{c}$ \\
\hline & Acetic/3.5 & $1.10 \pm 0.08^{b}$ & $1.14 \pm 0.21^{\mathrm{b}}$ \\
\hline \multirow[t]{4}{*}{ Protein } & Citric/2.0 & $3.87 \pm 0.54^{\mathrm{a}}$ & $4.14 \pm 0.67^{\mathrm{a}}$ \\
\hline & Citric/2.5 & $2.03 \pm 0.26^{b}$ & $2.11 \pm 0.39^{b}$ \\
\hline & Acetic/3.0 & $7.64 \pm 0.04^{c}$ & $8.14 \pm 0.95^{c}$ \\
\hline & Acetic/3.5 & $2.17 \pm 0.19^{b}$ & $2.47 \pm 0.51^{\mathrm{b}}$ \\
\hline \multirow[t]{4}{*}{ Water } & Citric/2.0 & $4.84 \pm 0.58^{a}$ & $5.39 \pm 0.22^{\mathrm{a}}$ \\
\hline & Citric/2.5 & $3.79 \pm 0.31^{b}$ & $3.67 \pm 0.52^{b}$ \\
\hline & Acetic $/ 3.0$ & $7.64 \pm 0.04^{\mathrm{c}}$ & $8.15 \pm 0.94^{c}$ \\
\hline & Acetic/3.5 & $5.56 \pm 0.15^{\mathrm{a}}$ & $5.31 \pm 0.33^{\mathrm{a}}$ \\
\hline \multirow[t]{4}{*}{ Total } & Citric/2.0 & $3.65 \pm 0.52^{a}$ & $3.97 \pm 0.59^{\mathrm{a}}$ \\
\hline & Citric/2.5 & $0.85 \pm 0.31^{b}$ & $1.09 \pm 0.26^{b}$ \\
\hline & Acetic/3.0 & $7.16 \pm 0.04^{c}$ & $7.67 \pm 0.95^{\mathrm{c}}$ \\
\hline & Acetic/3.5 & $1.07 \pm 0.10^{b}$ & $1.10 \pm 0.19^{b}$ \\
\hline
\end{tabular}

a, b, c Values designated with the same letter within a column are not significantly different $(P>0.05)$ as determined by Tukey's HSD. 
Table 2. Proximate analysis ${ }^{\mathrm{a}}$ of recovered trout proteins and insolubles that were solubilized at various $\mathrm{pH}$ values with citric and acetic acids and precipitated at $\mathrm{pH} 5.5$.

\begin{tabular}{lccccc}
\hline Component & $\begin{array}{c}\text { Treatment } \\
\text { (acid, pH) }\end{array}$ & $\begin{array}{c}\text { Moisture } \\
(\boldsymbol{\%})^{\boldsymbol{b}}\end{array}$ & $\begin{array}{c}\text { Lipid } \\
(\boldsymbol{\%} \text { dry } \\
\text { basis) }\end{array}$ & $\begin{array}{c}\text { Protein } \\
(\boldsymbol{\%} \text { dry basis })\end{array}$ & $\begin{array}{c}\text { Ash } \\
(\boldsymbol{\%} \text { dry } \\
\text { basis })\end{array}$ \\
\hline Protein & Citric, pH 2.0 & $79.53 \pm 0.69^{\mathrm{c}}$ & ND* $^{*}$ & $36.38 \pm 2.19^{\mathrm{c}}$ & $6.61 \pm 0.07^{\mathrm{a}}$ \\
Protein & Citric, pH 2.5 & $84.19 \pm 0.65^{\mathrm{b}}$ & $0.45 \pm 0.63^{\mathrm{b}}$ & $41.67 \pm 3.45^{\mathrm{b}, \mathrm{c}}$ & $6.57 \pm 0.58^{\mathrm{a}}$ \\
Protein & Acetic, pH 3.0 & $78.75 \pm 0.26^{\mathrm{c}}$ & $4.26 \pm 1.46^{\mathrm{a}}$ & $44.32 \pm 1.57^{\mathrm{b}}$ & $4.12 \pm 0.07^{\mathrm{a}, \mathrm{b}}$ \\
Protein & Acetic, pH 3.5 & $86.83 \pm 0.45^{\mathrm{a}}$ & $2.82 \pm 1.26^{\mathrm{a}, \mathrm{b}}$ & $54.49 \pm 0.92^{\mathrm{a}}$ & $1.18 \pm 0.66^{\mathrm{b}}$ \\
\hline Fish Paste & ------------ & $72.53 \pm 0.38$ & $5.25 \pm 1.74$ & $63.01 \pm 1.76$ & $1.99 \pm 0.31$ \\
\hline
\end{tabular}

${ }^{a}$ Data given are mean $\pm \mathrm{SD},(\mathrm{n}=3)$. * Indicates none detected (ND). Proximate analysis of headed, gutted trout: $72.53 \%$ moisture, 5.25\% total lipid (dry basis), $63.01 \%$ crude protein (dry basis), and 2.99\% ash (dry basis). ${ }^{b}$ Values designated with the same letter within a column are not significantly different $(P>0.05)$ as determined by Tukey's HSD. 


\title{
CHAPTER III
}

\section{ISOELECTRIC SOLUBILIZATION AND PRECIPITATION OF FISH PROTEIN USING CITRIC OR ACETIC ACID AND ITS EFFECT ON SURVIVAL OF LISTERIA MONOCYTOGENES}

\begin{abstract}
.
Isoelectric solubilization and precipitation (ISP) is a protein recovery process effective at reducing Listeria innocua, a nonpathogenic bacterium typically used as a surrogate for L. monocytogenes in recovered trout protein. The response of $L$. monocytogenes to ISP processing was determined and compared to the response of $L$. innocua. Headed, gutted rainbow trout were inoculated with L. monocytogenes, homogenized, and $\mathrm{pH}$-adjusted with granular citric acid ( $\mathrm{pH} 2.0$ and 2.5) or glacial acetic acid ( $\mathrm{pH} 3.0$ and 3.5). Proteins were solubilized and centrifugation was used to remove insoluble components (skin, insoluble protein, etc.). The supernatant was returned to the protein isoelectric point $(\mathrm{pH} 5.5)$ with $\mathrm{NaOH}$ and centrifuged to remove precipitated protein. Microbial load was enumerated on both growth and selective media; recovery was not significantly different $(P>0.05)$. Surviving cells from each component (protein, insoluble and water) were compared to initial inoculum numbers. Significant reductions were detected at all $\mathrm{pHs}(P<0.05)$. The greatest reductions were at $\mathrm{pH} 3.0$ with acetic acid, with a mean log reduction of 3.03 in the combined components, and a $3.53 \log$ reduction in the protein portion. Data were compared to results from a previous study using L. innocua. Significant differences $(P<0.05)$ in recovery were found between the two species at $\mathrm{pH} 2.0$ and 3.0 with greater recovery of L. monocytogenes, regardless of
\end{abstract}


processing $\mathrm{pH}$ or acid type. These results demonstrate the variability in resistance between species and indicate that $L$. innocua is not an appropriate surrogate for $L$. monocytogenes for ISP processing with organic acids.

\section{Introduction.}

Listeria monocytogenes is a Gram-positive, food borne pathogen that is responsible for approximately $27 \%$ of deaths related to food-borne illness in the US (Mead and others 1999). L. monocytogenes may be found in a wide range of ready-to-eat foods, milk and milk products, vegetables, meats, and seafood. While infection in healthy adults and children is rare, in an immunocompromised population L. monocytogenes may cause, septicemia, bacterial meningitis and/or encephalitis with a mortality rate of 20$30 \%$ (Ramaswamy and others 2007). Miscarriage, premature birth, or meningitis in newborns may occur if listeriosis is contracted during pregnancy (Ramaswamy and others 2007). The presence of $L$. monocytogenes in most raw fish products is believed to occur during contact with processing equipment (Wulff and others 2006).

L. monocytogenes is a facultative anaerobe that is resistant in up to $10 \% \mathrm{NaCl}$ solution, grows within wide $\mathrm{pH}$ and temperature ranges and is relatively heat tolerant (Friedly and others 2008). In addition, biofilm formation of certain strains increases the risk for contamination during processing (Friedly and others 2008). Because $L$. monocytogenes is such a resilient bacterium, it is advantageous to use a nonpathogenic surrogate in laboratory settings to decrease the risk of accidental ingestion or contamination. 
L. innocua is the most commonly encountered of the 6 Listeria species. L. innocua is the only species in the same phylogenetic cluster as L. monocytogenes (Chen and others 2009). Recently, L. innocua has been used as a surrogate for $L$. monocytogenes in studies examining different antimicrobial effects of processing treatments. Chill brine and lactic acid bacteria treatments (Boyer and others 2009), temperature treatments (Nufer and others 2007), liquid smoke treatments (Milly and others 2008), high pressure homogenization and nisin treatments (Pathanibul and others 2009), and organic and inorganic acid treatments (Otto and others 2010, Lansdowne and others 2009) have all utilized L. innocua as a surrogate. However, there is no data available that directly compares $L$. monocytogenes and L. innocua survival rates during processing that utilizes extreme $\mathrm{pH}$ shifts.

Exposure to extreme $\mathrm{pH}$ shifts, such as those required during isoelectric solubilization and precipitation (ISP) processing, has different effects on the survival and growth of Listeria. Phan-Thanh and Montagne (1998) found exposure to acetic acid at pH 3.5 left no survivors after one hour, while exposure to hydrochloric acid ( $\mathrm{HCl})$ at the same $\mathrm{pH}$ left $27 \%$ of the initial population alive. Lansdowne and others (2009) demonstrated that $\mathrm{pH}$ shifts with $\mathrm{HCl}$ used in ISP resulted in significant reductions in Listeria innocua populations, but did not demonstrate a net pasteurization effect, described as a 6-log reduction in Listeria numbers (USDA 2001). Otto and others (2010) verified a net pasteurization effect on L. innocua during ISP using organic acids. Therefore, objectives of this study were: 1) to determine the response of $L$. monocytogenes to ISP processing of rainbow trout (Oncorhynchus mykiss) with citric and acetic acids; 2) to compare the survival rates with $L$. innocua; and 3) to determine if $L$. 
innocua is an appropriate surrogate for L. monocytogenes in future ISP processing studies.

\section{Materials and Methods.}

Fish Preparation. Fresh rainbow trout (Oncorhynchus mykiss) were headed, gutted, and submerged in a $50 \mathrm{ppm}$ bleach solution for $10 \mathrm{sec}$ and drained for an additional $10 \mathrm{sec}$ (Clorox Regular Bleach, Clorox, Oakland, CA, USA). The sanitized trout was ground in a sanitized food processor (Cuisinart ProClassic7-Cup Food Processor, Cuisinart Co., East Windsor, NJ, USA) to a thick paste. The Cuisinart was placed under UV light (254nm) for $15 \mathrm{~min}$ after being cleaned with $70 \% \mathrm{ETOH}$ to achieve sanitation. The fish paste was portioned into freezer bags (Ziplock Freezer Bags, S.C. Johnson \& Son, Inc., Racine, WI, USA) and stored at $-80^{\circ} \mathrm{C}$.

Listeria Strain and inoculum preparation. Listeria monocytogenes lab strain FSL X1003 (L-2289) was obtained from the culture collection in the Department of Food Science and Technology at Virginia Polytechnic Institute and State University, Blacksburg, VA. This strain was revived in $100 \mathrm{~mL}$ sterile brain heart infusion (BHI; unless otherwise stated, all media were from Difco, Becton Dickinson, Sparks, MD, USA) and incubated $18-24 \mathrm{hrs}$ at $37^{\circ} \mathrm{C}$ and $50 \mathrm{RPM}$ in a rotary incubator(Classic C24, New Brunswick Scientific Co., Edison, NJ, USA). To create a working stock, initial culture was grown on sterile tryptic soy agar with $6 \%$ yeast extract (TSAYE) slants. Slants were incubated for $18-24 \mathrm{hr}$ at $37^{\circ} \mathrm{C}$ and then stored at $4^{\circ} \mathrm{C}$ to create a working stock.

Listeria monocytogenes was transferred into $100 \mathrm{~mL}$ sterile $\mathrm{BHI}$ flasks from the working stocks and incubated at $37^{\circ} \mathrm{C}$ and $50 \mathrm{RPM}$ in a rotary incubator. After $18-24 \mathrm{hrs,}$ 
contents of BHI flasks were centrifuged at $10,000 \times \mathrm{x}$ for $10 \mathrm{~min}$ at $4^{\circ} \mathrm{C}$ (Sorvall RC-SB Refrigerated Superspeed Centrifuge, Du Pont, Wilmington, DE, USA). Supernatant was removed and remaining unwashed pellet was used to inoculate $155 \mathrm{~g}$ fish paste. The initial target inoculum level was $10^{9} \mathrm{CFU} / \mathrm{g}$ (Lansdowne and others 2009). Actual initial average inoculum level was $1.45 \times 10^{10} \mathrm{CFU} / \mathrm{g}$.

Inoculation of Fish Paste. One previously portioned bag of fish paste was thawed 18-24 hrs at $4^{\circ} \mathrm{C}$. The fish paste was emptied into an autoclaved ceramic dish. The unwashed L. monocytogenes pellet was incorporated into the fish paste by mixing with an autoclaved spatula. The inoculated fish paste immediately subjected to isoelectric solubilization and precipitation (ISP) processing.

Isoelectric solubilization and precipitation (ISP) processing. Methodology for the ISP process has been described elsewhere (Lansdowne and others 2009; Otto and others 2010). Briefly, inoculated fish paste (107 g) was homogenized with $693 \mathrm{~mL}$ distilled, deionized water in an autoclaved $2000 \mathrm{~mL}$ glass beaker. Sanitation of the homogenizer (PowerGen 700, Fisher Scientific, Pittsburgh, PA) was achieved by wiping with 70\% ETOH and drying under UV light (254nm) for $15 \mathrm{~min}$. Glacial acetic acid (Fischer Scientific, Fairlawn, NJ, USA) or granular citric acid (Fischer Scientific, Fairlawn, NJ, USA) was added to the homogenate until the target $\mathrm{pH}(2.0,2.5$ for citric and 3.0, 3.5 for acetic) was reached. The solution was homogenized for 5 min, during which $\mathrm{pH}$ changes were maintained by addition of citric or acetic acid or $10 \mathrm{~N} \mathrm{NaOH}$. After adjustments, homogenization was continued for an additional 10 min to allow protein solubilization. The homogenized fish mixture was transferred to autoclaved centrifuge tubes and centrifuged at $10,000 \times \mathrm{x}$ for $10 \mathrm{~min}$ at $4^{\circ} \mathrm{C}$ (Sorvall RC-SB Refrigerated Superspeed 
Centrifuge, Du Pont, Wilmington, DE, USA) to separate the insoluble portions of the solution. The supernatant was poured and the insoluble components were removed. The supernatant, consisting of water and solubilized protein, was brought to its isoelectric point ( $\mathrm{pH} 5.5$ ) with the addition of $10 \mathrm{~N} \mathrm{NaOH}$. After a 5 min adjustment period to ensure a $\mathrm{pH}$ of 5.5, $10 \mathrm{~min}$ of homogenization was conducted to allow for protein precipitation. The homogenate was again centrifuged at $10,000 \times \mathrm{x}$ for $10 \mathrm{~min}$ at $4^{\circ} \mathrm{C}$. Following centrifugation, the resulting supernatant, comprised mostly of water, was poured off through autoclaved cheesecloth into an autoclaved $500 \mathrm{~mL}$ flask. The remaining protein fraction was transferred into an autoclaved $250 \mathrm{~mL}$ beaker using an autoclaved spatula. Average total processing time was $90 \mathrm{~min}$.

Microbial Analysis. Microbial analysis was performed on non-inoculated thawed fish paste to determine background flora (background), inoculated fish paste (initial), and all of the recovered components: insolubles, protein, and water. One gram from all components (background, initial, insolubles, protein and water) was mixed in separate, sterile stomacher bags with $9 \mathrm{~mL}$ sterile peptone buffer. Each component was serially diluted (tenfold) with sterile peptone buffer and $0.1 \mathrm{~mL}$ was spread plated on both nonselective media (TSAYE) and selective media (modified oxford agar, MOX) in duplicate. The plates were incubated for $24 \mathrm{hrs}$ at $37^{\circ} \mathrm{C}$ (Classic C24, New Brunswick Scientific Co., Edison, NJ, USA). The detection limit for uninoculated fish paste was $<10^{3} \mathrm{CFU} / \mathrm{g}$; $<10^{3} \mathrm{CFU} / \mathrm{g}$ for proteins and insoluble analyses, and $<10^{2} \mathrm{CFU} / \mathrm{g}$ for the water fraction. Total $\log$ reductions were calculated by subtracting the total survivors in each fraction from the initial inoculum: $\log ($ initial inoculum $)-\log ($ survivors in protein + insolubles + 
water fractions). The log reduction for each fraction: $\log$ (initial inoculum) $\log$ (survivors in specific fraction).

Statistical Analysis. The experiments were replicated in triplicate for each $\mathrm{pH}$ value. Recovered cells were expressed as $\log _{10} \mathrm{CFU} / \mathrm{g}$. Microbial count (CFU/g) were converted into logarithmic units and differences in microbial recovery for each component and on each medium were determined by one-way analysis of variance and Tukey-Kramer's honestly significant difference test $(P<0.05)$ (JMP 7, SAS Inst., Cary, N.C., USA).

\section{Results and Discussion.}

For all trials, the average background flora of the uninoculated fish paste was 4.54 $\mathrm{x} 10^{3} \mathrm{CFU} / \mathrm{g}$ on TSAYE. There was no detected growth of Listeria $\left(<10^{2} \mathrm{CFU} / \mathrm{g}\right)$ on MOX. No significant differences $(P>0.05)$ were found in recovery of cells on selective media (MOX) versus growth media (TSAYE), suggesting acidic conditions created by organic acids have a bactericidal effect that leaves no injured L. monocytogenes cells. A net pasteurization effect, defined by USDA as a 6-log reduction in Listeria (USDA 2001), was not observed for the protein or insoluble fractions with the use of either acid at any of the $\mathrm{pH}$ levels (Table 1). A pasteurization effect was observed with a log reduction of 6.76 on MOX and 7.13 on TSAYE in the water fraction with the use of acetic acid at $\mathrm{pH} 3.0(P<0.05)$. However, the water fraction derived during ISP would usually be discarded and have no potential use in products for human or animal consumption. Although not significantly different $(P>0.05)$, the greatest log reductions in bacterial populations were observed in all fractions and in total with the use of acetic 
acid at a processing $\mathrm{pH}$ of 3.0. The fewest microbial reductions occurred with the use of citric acid, at the ISP processing $\mathrm{pH}$ of 2.5. The insoluble fraction contained most of the recovered cells (Figure 2), except at $\mathrm{pH}$ 3.0, and the water portion contained the fewest. As described by Lansdowne and others (2009), centrifugation is likely responsible for the high numbers of recovered cells in the insoluble fraction, removing the number of potential cells to be left within the protein and water fractions. Lipid fractions in other ISP trials have contained up to $17 \%$ of recovered Listeria cells (Lansdowne and others 2009). Lipids were not recoverable during processing in this trial, due to the relatively small sample volumes used. Proximate analysis conducted in a previous study with the same fish byproducts (Otto and others 2010) revealed that lipids were present within the protein fractions after treatment with acetic acid at $\mathrm{pH} 3.0$ and 3.5 and citric acid at $\mathrm{pH}$ 2.5. The only lipid identified in the insoluble fraction was with the treatment of acetic acid at $\mathrm{pH}$ 3.5. This may be important because a high fat content in foods has a protective effect on Listeria when subjected to acidic conditions (Waterman and Small 1998; Barmpalia-Davis and others 2009). However, the highest lipid content (4.26\%) was within the protein portion at acetic acid at $\mathrm{pH} 3.0$, which had the greatest bactericidal effects in the protein portions. In this instance, it is probable that the lipid concentration was not great enough to provide protection for L. monocytogenes.

Organic acids, applied as a wash, spray, dip, or included in product formulations are commonly used in the food industry to deter growth of L. monocytogenes (Carpenter and Broadbent 2009). Exposure to acetic acid at $\mathrm{pH} 3.5$ or $\mathrm{HCL}$ at $\mathrm{pH} 3.0$ for $60 \mathrm{~min}$ would leave no surviving cells (Phan-Thanh and Montagne 1998; Davis and others 1996) and L. monocytogenes is unable to grow below $\mathrm{pH}$ 4.5-4.6 (Koutsoumanis and others 
2003). Organic, weak acids lower intracellular $\mathrm{pH}$ more effectively than inorganic, strong acids. Strong acids dissociate outside of the cell, within the solution, while weak acids diffuse through cell walls and dissociate once inside. In Phan-Thanh and Montagne (1998), results showed that when acetic acid is used rather than $\mathrm{HCl}$ to create an extracellular $\mathrm{pH}$ of 3.5, intracellular $\mathrm{pH}$ is lower with the use of acetic acids (pHs of 3.34 and 4.22, respectively). Once the organic acid has dissociated within the cell, it is unable to diffuse out, thus killing the cell through a number of mechanisms: the accumulation of anions within the cell may increase osmolarity and increase pressure, causing the cell to burst; other cellular anions, mainly glutamate, may be expelled to compensate, lowering intracellular $\mathrm{pH}$ and inhibiting cell function; and/or direct feedback inhibition of crucial metabolic pathways caused by anion accumulation (Carpenter and Broadbent 2009).

Listeria has the ability to develop levels of acid resistance or acid tolerance when subjected to sublethal pH levels (Shen and others 2006; Moorman and others 2008; PhanThanh and Montagne 1998; Ferreira and others 2003). L. monocytogenes in slightly acidic food will resist highly acidic treatments by upregulating specific proteins that alter the structure of membranes, increasing the cell's ability to maintain intracellular $\mathrm{pH}$ (Phan-Thanh and Montagne 1998). In addition to acid tolerance, nutrient and protein rich media modifies phospholipids in bacteria, allowing $L$. monocytogenes to survive otherwise lethal acidic conditions (Phan-Thanh and Montagne 1998).

Differences in log reductions were compared to results from a previous study by the same authors with L. innocua (Table 2) (Otto and others 2010). For both acid types and all $\mathrm{pH}$ values tested, $L$. monocytogenes was more resistant to ISP processing than $L$. innocua. There were significant differences in survival rates $(P<0.05)$ with citric acid at 
$\mathrm{pH} 2.0$ and acetic acid at $\mathrm{pH} 3.0$. In both cases, bacterial reductions were greater in $L$. innocua than reductions in L. monocytogenes. Combined MOX and TSAYE data for total fractions (Table 2) reveals that citric acid at $\mathrm{pH} 2.0$ and acetic acid at $\mathrm{pH} 3.0$ led to a log reduction in L. monocytogenes of $1.12 \pm 0.11$ and $3.03 \pm 0.14$, respectively. The same treatments on $L$. innocua led to a total $\log$ reduction in on combined media of $3.85 \pm 0.23$ with citric at $\mathrm{pH} 2.0$ and $7.42 \pm 0.36$ with acetic at $\mathrm{pH} 3.0$.

One mechanism that contributes to bacterial survival under stressors is redirection of transcription through alternative sigma factors. Sigma factors are protein subunits that enable binding of bacterial RNA polymerase to specific gene promoters. $\sigma^{\mathrm{B}}$, a sigma factor seen in Gram positive bacteria, plays a role in acid tolerance exhibited by Listeria (Raengpradub and others 2008). However, the genes regulated by $\sigma^{\mathrm{B}}$ are species specific. L. monocytogenes and L. innocua both appear to share $49 \sigma^{\mathrm{B}}$-dependent genes, but $L$. monocytogenes has $>140$ genes that are thought to be both negatively and positively regulated by $\sigma^{\mathrm{B}}$ (Raengpradub and others 2008). Differences in survival between the two species may be that the $\sigma^{\mathrm{B}}$-stress response has adapted in L. monocytogenes to fit a pathogenic lifestyle — by adapting quickly to survive a low $\mathrm{pH}$, as found in gastric fluid (Raengpradub and others 2008; Ferreira and others 2003).

The effect of protein recovery in ISP using extreme $\mathrm{pH}$ shifts to reduce populations of L. monocytogenes showed that none of the treatments tested (citric acid at pH 2.0 and 2.5 or acetic acid at 3.0 and 3.5) resulted in a net pasteurization effect (6-log reduction in microbial population), although use of acetic acid at $\mathrm{pH} 3.0$ and citric acid at pH 2.0 demonstrated significant $(P<0.05)$ microbial reductions. When compared to survival rates of $L$. innocua, L. monocytogenes was more resistant the ISP process $(P>$ 
0.05). These results demonstrate the variability in resistance between species and indicate that L. innocua is not an appropriate surrogate for L. monocytogenes for ISP processing with organic acids. 


\section{References}

Barmpalia-Davis IM, Geornaras I, Kendall PA, and Sofos JN. 2009. Effect of fat content on survival of Listeria monocytogenes during simulated digestion of inoculated beef frankfurters stored at $7^{\circ} \mathrm{C}$. Food Microbiol 26(5): 483-490.and

Boyer RR, Matak K, Meadows B, Williams RC, Eifert JD, and Birbari W. 2009. Survival of Listeria monocytogenes, Listeria innocua, and lactic acid bacteria in chill brines. $\mathrm{J}$ Food Sci 74(5): M219-M223.

Carpenter CE and Broadbent JR. 2009. External concentration of organic acid anions and $\mathrm{pH}$ : key independent variables for studying how organic acids inhibit growth of bacteria in mildly acidic foods. J Food Sci 74(1): R12-R15.

Chen J, Jiang L, Chen X, Luo X, Chen Y, Yu Y, Tian G, Liu D and Fang W. 2009. Listeria monocytogenes serovar $4 \mathrm{a}$ is a possible evolutionary intermediate between Listeria monocytogenes serovars $1 / 2 \mathrm{a}$ and $4 \mathrm{~b}$ and L. innocua. J Microbial Biotechnol 19(3):238-249.

Davis M, Coote P, and O'Byrne C. 1996. Acid tolerance in Listeria monocytogenes: the adaptive acid tolerance response (ATR) and growth-phase-dependent acid resistance. Microbiology. 142:2975-2982.

Ferreira A, Sue D, O’Byrne CP, and Boor KJ. 2003. Role of Listeria monocytogenes $\sigma^{\mathrm{B}}$ in survival of lethal acidic conditions and in the acquired acid tolerance response. App Environ Microbiol 69(5):2692-2698.

Friedly EC, Crandall PR, Ricke S, O’Bryan CA, Martin EM, and Boyd LM. 2008. Identification of Listeria innocua surrogates for Listeria monocytogenes in hamburger patties. J Food Sci 73(4): M174-178.

Guilbaud M, Chafesy I, Pilet M, Leroi F, Prevost H, Heraud M, and Dousset X. 2008. Response of Listeria monocytogenes to liquid smoke. J Appl Microbiol 104:1744-1753.

Koutsoumanis K, Kendall P, and Sofos J. 2003. Effect of food processing-related stresses on acid tolerance of Listeria monocytogenes. Appl Environ Microbiol 69(12):7514-7516.

Lansdowne LR, Beamer S, Jaczynski J, and Matak KE. 2009. Survival of Listeria innocua after isoelectric solubilization and precipitation of fish protein. J Food Sci 74(4): M201-205.

Mead PS, Slutsker L, Dietz V, McCraig F, Bresee S, Shapiro C, Griffin PM, and Tauxe RV. 1999. Food-related illness and death in the United States. Emerg Infect Dis 5:607625. 
Milly PJ, Toledo RT, and Chen J. 2008. Evaluation of liquid smoke treated ready-to-eat (RTE) meat products for control of Listeria innocua M1. J Food Sci 73(4):M179-183.

Moorman MA, Thelemann CA, Zhou S, Pestka JJ, Linz JE and Ryser ET. 2008. Altered hydrophobicity and membrane composition in stress-adapted Listeria innocua. J Food Prot 71(1):182-185.

Nufer U, Stephan R, and Tasara T. 2007. Growth characteristics of Listeria monocytogenes, Listeria welshimeri, and Listeria innocua strains in broth cultures and a sliced bologna-type product at 4 and $7^{\circ}$ C. Food Microbiol 24:444-451.

Otto R, Beamer S, Jaczynski J, and Matak K. 2010. Survival of Listeria innocua after isoelectric solubilization/precipitation with acetic and citric acids. Submitted for publication.

Pathanibul P, Taylor TM, Davidson PM, and Harte F. 2009. Inactivation of Escherichia coli and Listeria innocua in apple and carrot juices using high pressure homogenization and nisin. Int J Food Microbiol 129(3): 316-320.

Phan-Thanh L and Montagne A. 1998. Physiological and biochemical aspects of the acid survival of Listeria monocytogenes. J Gen Appl Microbiol 44:183-191.

Raengpradub S, Wiedmann M, and Boor KJ. 2008. Comparative analysis of the $\sigma^{\mathrm{B}}$ dependent stress responses in Listeria monocytogenes and Listeria innocua strains exposed to selected stress conditions. Appl Environ Microbiol 74(1) 158-171.

Ramaswamy V, Cresence VM, Rejitha JA, Lekshmi MU, Dharsana KS, Prasad SP, and Nijila HM. 2007. Listeria - review of epidemiology and pathogenesis. J Microbiol Immunol Infect. 40:4-13.

Shen Y, Liu Y, Zhang Y, Cripe J, Conway W, Meng J, Hall G, and Bhagwat A. 2006. Isolation and characterization of Listeria monocytogenes isolates from ready-to-eat foods in Florida. Appl Environ Microbio. 72(7): 5073-5076.

Swaminathan B. 2001. Listeria monocytogenes. In: Doyle MP, Beuchat LR, Montville TJ, editors. Food microbiology: fundamentals and frontiers. $2^{\text {nd }}$ ed. Washington DC: ASM Press. P 383-409.

[USDA] United States Food and Drug Administration. 2001. Fish and fisheries products hazards and controls guidance: chapter 17. Available from: http://www.fda.gov/Food/GuidanceComplianceRegulatoryInformation/GuidanceDocume nts/Seafood/FishandFisheriesProductsHazardsandControlsGuide/ucm119783.html. Accessed Jan 23, 2010. 
Van Coillie E, Werbrouck H, Heyndricks M, Herman L, and Rijpens N. 2004.

Prevalence and typing of Listeria monocytogenes in ready-to-eat food products on the Belgian market. J Food Prot 67(11):2480-2487.

Waterman SR, and Small PLC. 1998. Acid-sensitive enteric pathogens are protected from killing under extremely acidic conditions of $\mathrm{pH} 2.5$ when they are inoculated onto certain solid food surfaces. Appl Environ Microbiol 64(10): 3882-3886.

Wulff G, Gram L, Ahrens P, and Vogel BF. 2006. One group of genetically similar Listeria monocytogenes strains frequently dominates and persists in several fish slaughter-and smokehouses. Appl Environ Microbiol 72(6):4313-4322. 
Figure 1: Recovery process of functional proteins with isoelectric solubilization and precipitation

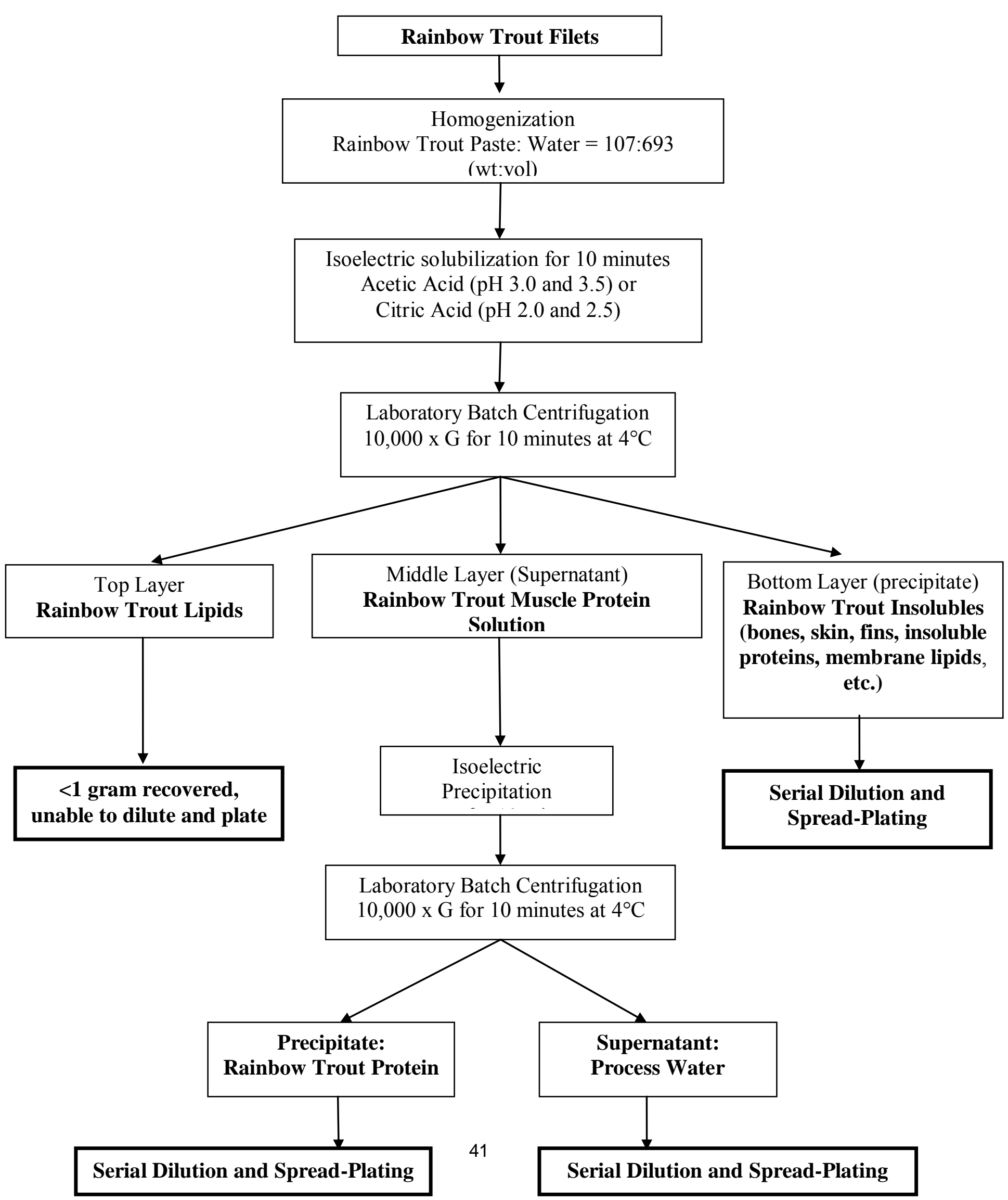




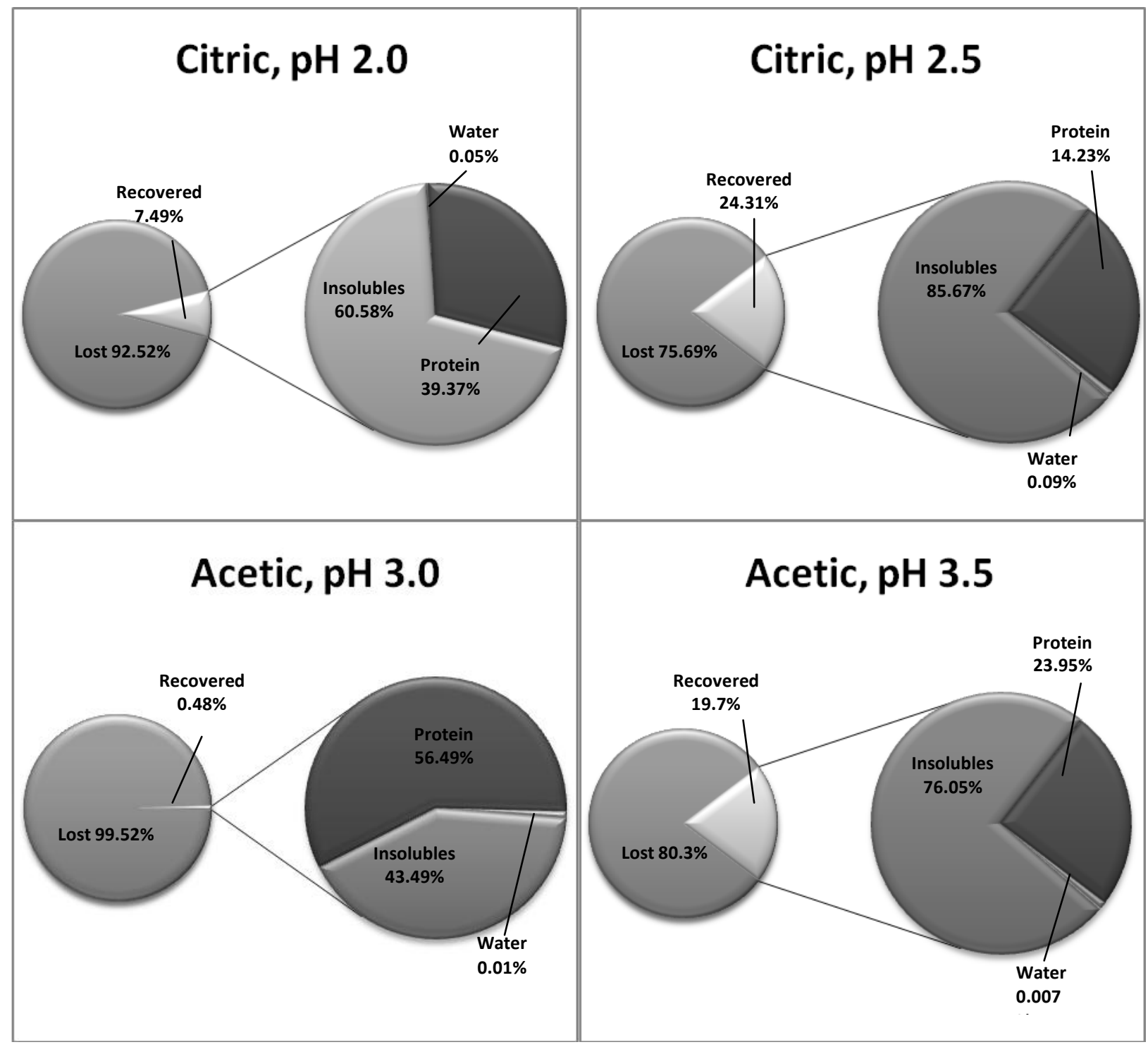

FIGURE 2. Recovered L. monocytogenes after ISP processing. The left pie chart indicates the percentage of recovered and inactivated (lost) cells from the initial inoculum. The right chart represents the fraction in which the recovered cells were found. Data represents combined recovery on TSAYE and MOX, as there were no significant differences in recovery $(\mathrm{P}>0.05)$. Total log reduction was calculated as follows: $\log$ (initial inoculum) - $\log$ (survivors in insoluble fraction + protein fraction + water fraction). Log reduction for each fraction: $\log$ (initial inoculum) $-\log$ (survivors in fraction). 
Table 1. Log reduction of L. monocytogenes lab strain FSL X1-003 (L-2289) exposed to acidic $\mathrm{pH}$ shifts with the addition of acetic or citric acids in various fractions of headed and gutted rainbow trout. Values were determined by subtraction of the log of recovered cells within a fraction from the log of the total inoculation. There were no significant differences in recovery between TSAYE and $\operatorname{MOX}(P>0.05)$.

\begin{tabular}{|c|c|c|c|}
\hline \multirow[b]{2}{*}{ 3) } & \multirow[b]{3}{*}{ Acid/pH } & \multirow[b]{3}{*}{ MOX } & \multirow[t]{2}{*}{$\begin{array}{c}\text { Log Reduction } \\
\text { (mean } \log \mathrm{CFU} / \mathrm{g} \pm \mathrm{SD}, n=\end{array}$} \\
\hline & & & \\
\hline Fraction & & & TSAYE \\
\hline \multirow[t]{4}{*}{ Insoluble } & Citric/2.0 & $1.40 \pm 0.18^{\mathrm{a}}$ & $1.28 \pm 0.22^{a}$ \\
\hline & Citric/2.5 & $0.68 \pm 0.18^{a}$ & $0.87 \pm 0.22^{\mathrm{a}}$ \\
\hline & Acetic/3.0 & $3.73 \pm 1.26^{\mathrm{a}}$ & $3.62 \pm 0.42^{b}$ \\
\hline & Acetic/3.5 & $0.72 \pm 1.26^{\mathrm{a}}$ & $1.14 \pm 0.42^{\mathrm{a}}$ \\
\hline \multirow[t]{4}{*}{ Protein } & Citric/2.0 & $1.79 \pm 0.26^{\mathrm{a}}$ & $1.44 \pm 0.02^{\mathrm{a}}$ \\
\hline & Citric/2.5 & $1.42 \pm 0.26^{\mathrm{a}}$ & $1.48 \pm 0.02^{\mathrm{a}}$ \\
\hline & Acetic $/ 3.0$ & $3.52 \pm 0.64^{\mathrm{a}}$ & $3.53 \pm 0.35^{b}$ \\
\hline & Acetic/3.5 & $1.58 \pm 0.64^{\mathrm{a}}$ & $1.55 \pm 0.35^{\mathrm{a}}$ \\
\hline \multirow[t]{4}{*}{ Water } & Citric/2.0 & $4.39 \pm 0.03^{a}$ & $4.36 \pm 0.55^{a}$ \\
\hline & Citric/2.5 & $4.92 \pm 0.03^{\mathrm{a}}$ & $4.41 \pm 0.55^{\mathrm{a}}$ \\
\hline & Acetic/3.0 & $6.76 \pm 0.24^{b}$ & $7.13 \pm 0.44^{b}$ \\
\hline & Acetic/3.5 & $5.13 \pm 0.24^{\mathrm{a}}$ & $4.71 \pm 0.44^{\mathrm{a}}$ \\
\hline \multirow[t]{4}{*}{ Total } & Citric/2.0 & $1.20 \pm 0.09^{\mathrm{a}}$ & $1.04 \pm 0.09^{\mathrm{a}}$ \\
\hline & Citric/2.5 & $0.62 \pm 0.29^{\mathrm{a}}$ & $0.76 \pm 0.29^{\mathrm{a}}$ \\
\hline & Acetic $/ 3.0$ & $2.93 \pm 1.91^{\mathrm{a}}$ & $3.13 \pm 0.86^{b}$ \\
\hline & Acetic/3.5 & $0.63 \pm 0.46^{\mathrm{a}}$ & $0.96 \pm 0.14^{\mathrm{a}}$ \\
\hline
\end{tabular}

${ }^{a, b}$ Values designated with the same letter within a column and fraction are not significantly different $(\mathrm{P}>0.05)$ 
Table 2. Total (protein, insoluble, and water fractions combined) log reductions of L. monocytogenes (LI) and L. innocua (LI) exposed to different $\mathrm{pH}$ shifts using acetic and citric acids in rainbow trout. ${ }^{a}$ Values were determined by subtraction of the log of total recovered cells from the log of the total initial inoculation. Combined data from MOX and TSAYE. There were no significant differences in recovery between MOX and TSAYE $(P>0.05)$.

\begin{tabular}{cccc}
\hline \multirow{2}{*}{ Fraction } & Acid/pH & $\begin{array}{c}\text { Bacterial } \\
\text { Strains }\end{array}$ & $\begin{array}{c}\text { Log Reduction } \\
\text { (mean log CFU/g } \pm \text { SD, } \boldsymbol{n}= \\
\mathbf{3} \text { ) }\end{array}$ \\
\cline { 2 - 4 } & \multirow{2}{*}{ Citric pH 2.0* } & LM & $1.12 \pm 0.11$ \\
\cline { 2 - 4 } TOTAL & LI & $3.85 \pm 0.23$ \\
\cline { 2 - 4 } & \multirow{2}{*}{ Citric pH 2.5 } & LM & $0.69 \pm 0.09$ \\
\cline { 2 - 4 } & \multirow{2}{*}{ Acetic pH 3.0* } & LI & $0.97 \pm 0.17$ \\
\cline { 2 - 4 } & \multirow{2}{*}{ Acetic pH 3.5 } & LI & $3.03 \pm 0.14$ \\
& LM & $7.42 \pm 0.36$ \\
\hline
\end{tabular}

* Indicates significant difference in reductions between strains within treatment. $(P<0.05)$. 